\title{
Judicial independence and the validity of controverted elections*
}

\author{
Raphaël Franck \\ Bar Ilan University
}

\begin{abstract}
This article examines whether the judges of the French Constitutional Court demonstrated partisanship when ruling on the validity of the elections to the lower house of the French Parliament between 1958 and 2005. It uses a new dataset on the decisions of the Constitutional Court which takes into account the characteristics of the controverted parliamentary elections. The rulings of the Constitutional Court are found to be biased against far-right candidates. However, the judges are also found to display some form of independence vis-à-vis the government since they do not favor candidates from the ruling party when they render their decisions.
\end{abstract}

Keywords: Judicial independence; Judicial politics; Judges; Parliamentary elections. JEL Code: D72, D73, H11.

\footnotetext{
* Bar Ilan University, Department of Economics, 52900 Ramat Gan, Israel. Tel: 972-3-531-8935. Fax: 972-3-7384034. Email: franckr@mail.biu.ac.il.

This paper benefited from helpful comments from Bryan Caplan, Robin Hanson, Abraham Lioui, Michael Makowsky, Ilia Rainer, Hillel Rappaport, Alex Tabarrok, Samia Tavares and seminar participants at the Public Choice Seminar at George Mason University. Michel Clauzel and the personnel at the archives of the Assemblée Nationale were very helpful in providing the data on the parliamentary elections. Part of this research was conducted while I was visiting the Center for the Study of Public Choice at George Mason University, whom I thank for its hospitality. Financial support from the Adar Foundation of the Economics Department of Bar-Ilan University is gratefully acknowledged. The usual disclaimer applies.
} 


\section{Introduction}

In a series of studies, La Porta et al. $(1997,1998,1999)$ argue that British common law provides a legal framework which is more favorable to economic growth than French civil law. In particular, they contend that property rights are better protected under British common law than under French civil law because the former grants judges higher independence from the polity than the latter. This makes judges in British common law countries more likely to prevent the government from seizing private property through eminent domain. In this respect, Berkowitz and Clay (2005, 2006) provide some empirical support for the claims of La Porta et al. $(1997,1998,1999)$ by showing that judicial independence is low in US states that initially had a civil law regime.

However, studies by Hanssen (2004), Iaryczower et al. (2002) and Ramseyer and Rasmusen $(1997,2001)$ consider that judicial independence is not necessarily lower in civil law than in common law countries. Instead, they argue that the independence of the judiciary mainly depends on the judges’ appointment process to the courts, on the length of the courts' tenure and on political circumstances. In particular, Hanssen (2004) shows that independent judiciaries are more likely to emerge in political environments where major differences exist between party platforms and where there is a high degree of competition between parties.

This paper seeks to examine the claim that judicial independence in countries with a French civil law regime is low by focusing on the rulings of the Conseil Constitutionnel (Constitutional Council - CC), the French constitutional court. Its approach however differs from most of the

\footnotetext{
${ }^{1}$ La Porta et al. (2008) provide additional explanations for the higher growth rates of common law countries. They notably argue that common law is more flexible than civil law, and as a result, provide a freer and safer contracting environment for business organization. This explanation has however been criticized by Lamoreux and Rosenthal
} (2005). 
research on judicial independence, e.g., Gely and Spiller (1990, 1992), Spiller and Gely (1992), Segal and Spaeth (2002), because it does not focus on the judiciary's willingness to rescind nonconstitutional decisions.

Instead, this article exploits the fact that the CC judges have ruled on the validity of parliamentary elections since the creation of the court in 1958, when the Fifth French Republic was established. ${ }^{2}$ It would seem that the positive political theories of court rulings on nonconstitutional issues and on the validity of elections are quite different. Judicial decisions can be reversed when courts rule on non-constitutional matters. However, if the judges pick the winner and the loser(s) in an election, there is not much that the latter can do to overturn the judges' decision, apart from starting a popular uprising.

As such, if judicial independence in countries with a French civil law regime is low, as La Porta et al. (2008) suggest, it may be hypothesized that the CC judges are explained by the party currently in power: the CC judges would validate the controverted elections of the representatives from the ruling party and/or invalidate the victories of candidates from the opposition parties. Conversely, if the CC judges are independent, the rulings of the CC judges may be based on purely legal and apolitical criteria and/or may be explained by the political

\footnotetext{
${ }^{2}$ There are several countries where constitutional court judges may be called upon to render rulings on the validity of elections. Recent examples include the US Supreme Court's Bush v. Gore decision in the 2000 US presidential election and the Mexican Supreme Court's ruling following the 2006 presidential election in Mexico. Hasen (2004) reviews the literature on the Bush v. Gore decision. See Giordano (2006) for a discussion of the 2006 Mexican presidential election.
} 
biases of the CC judges, since all the CC judges have been nominated by politicians, and since some CC judges were even former politicians. ${ }^{3}$

This paper thus assesses the CC's judicial independence by examining its rulings on the validity of the elections of the representatives elected to the lower house of the French Parliament between 1958 and 2005. During this period, the CC pronounced 2229 rulings concerning electoral races in 12 general parliamentary elections and in many by-elections ${ }^{4}$. These rulings constitute the basis for this paper's dataset, which also comprises information on the CC judges and on the characteristics of the elections whose validity was questioned, e.g., the difference in the number of votes between the two front-running candidates and the political affiliation of the elected candidate.

It must be noted that the vote of each CC judge remains unknown and that only the final decision of the CC is made public. In spite of this limitation, our results provide evidence that the rulings of the CC judges are biased against far-right candidates, whose elections are almost always annulled when the CC finds evidence of irregularities.

In the French political context, the partisanship displayed by the CC judges against farright candidates may be given a rational-choice explanation. First, all the CC judges have been appointed either by mainstream right-wing or mainstream left-wing politicians, who oppose the

\footnotetext{
${ }^{3}$ Franck (2009) shows that the CC's decisions on constitutional matters are influenced by the specific political circumstances at the time of each ruling: CC judges are more likely to render independent decisions when the polity is fragmented between left-wing and right-wing parties. See also Stone (1992) on this issue.

${ }^{4}$ While the rulings of the CC on the validity of elections never entailed a change in the political majority in Parliament, they may have consequences on the legitimacy of the elected candidate and on the redistributive policies undertaken at the local level. Studies on the relationship between the composition of the legislature and public spending include Del Rossi and Inman (1999), Bradbury and Crain (2001) and Gilligan and Matsusaka (2001).
} 
far-right. This observation suggests that CC judges would be biased against far-right candidates. More generally, it reflects the general consensus in mainstream French society, from which all the CC judges are drawn, that the far-right is politically "beyond the pale". ${ }^{5}$ Second, selfinterested CC judges, who care about the preservation of their prerogatives, know they have nothing to fear from far-right politicians. This is because far-right candidates could only threaten the CC's independence if they became junior or senior partners in governmental coalitions after the parliamentary elections. But far-right politicians have never exercised any political responsibility at the national level since 1958 . Hence, our results suggest that a combination of political ideology and self-interest on the part of the CC's judges explains why they rendered partisan rulings against far-right candidates, but not against candidates of other parties. But they also suggest that the CC judges are also independent from the polity since their decisions are not influenced by the ruling party when they render their decisions.

The rest of this article is as follows. Section 2 discusses the powers of the Conseil Constitutionnel (CC). Section 3 presents the data while Section 4 deals with the econometric methodology. Section 5 analyzes the estimation results and Section 6 concludes. The Appendix provides excerpts of CC judgments on controverted elections.

\section{The powers of the Conseil Constitutionnel}

Articles 56 to 63 of the Constitution of the Fifth French Republic and the 7 November 1958 Ordonnance n ${ }^{\circ 58-1067}$ define the organization and the main functions of the CC. In this section, we discuss how they shape the appointments of the CC judges and the validation process of elections.

\footnotetext{
${ }^{5}$ Since 1958, the mainstream right-wing parties have systematically refused alliances with the far-right, in local and in national elections. The seminal work on the different ideological groups of the French Right is Rémond (1982).
} 


\subsection{The appointment of the CC judges}

Nine judges sit on the CC's bench. Their term lasts nine years and is not renewable. Three judges, including the CC president ${ }^{6}$, are nominated by the President of the French Republic, three by the President of the Assemblée Nationale, the lower house of Parliament, and three by the President of the Sénat, the upper house of Parliament. Every three years, three judges leave the bench and are replaced by three newcomers.

In addition to the nine judges, former Presidents of the French Republic are members of the CC in their own right. However, only three sat. President Vincent Auriol joined the CC in 1958 but boycotted its proceedings after 1962 to protest against the amendment to the French Constitution providing for the election of the President of the Republic by the people in a general election. In the last quarter of 2005, President Valéry Giscard d’Estaing was the first former President since Vincent Auriol to attend some of the proceedings of the CC, but not any dealing with the elections to the lower house of Parliament. President Jacques Chirac also joined the CC in the fall of 2007.

Between 1958 and 2005, five women and sixty men sat on the CC's bench ${ }^{7}$. Even though no qualification is required to become a CC judge, many were lawyers, high-level civil servants, and professors of law or political science. There were also several former parliamentarians, from both the lower and the upper houses of Parliament. It must be noted that CC judges cannot be at the same time government ministers or members of Parliament, and more generally, cannot run in any election.

\footnotetext{
${ }^{6}$ In addition to his duties as a judge, the CC president is entrusted with the administration of the CC.

${ }^{7}$ Detailed biographical information on each CC judge is available upon request.
} 
Between 1958 and 2005 (i.e., the end of our sample), all the politicians who nominated CC judges belonged to the mainstream left-wing or to the mainstream right-wing parties. This is shown in Figure 1, which provides the relative shares of judges appointed by mainstream rightwing and mainstream left-wing politicians sitting on the CC's bench in the years when general parliamentary election were held. Figure 1 shows that, since 1958, the CC has been dominated by judges appointed by mainstream-wing politicians, except between 1988 and 2001. This observation suggests that the political affiliation of the politicians who appointed the CC judges, as well as the political party in power at the time of the rulings, should be taken into account to explain the CC's decisions on controverted elections.

\section{[Insert Figure 1]}

\subsection{The validation process of elections}

The CC's competence for judging the validity of the parliamentary elections is defined by Chapters 6 and 7 of the 7 November 1958 Ordonnance ${ }^{\circ} 58-1067^{8}$. These laws prevent the CC from judging the validity of all the elections. It can only investigate the lawfulness of an election when a complaint is filed. But the procedure for filing such a complaint must obey specific rules. A complaint is only valid if it is filed by a candidate who ran in the controverted election or by a voter who was registered to vote in the election ${ }^{9}$. The CC can thus dismiss requests from government ministers or civil servants who question the validity of the election if they were not themselves candidates or did not live in the constituency. Complaints that are submitted more

\footnotetext{
${ }^{8}$ Before the establishment of the Fifth Republic in 1958, and the ensuing creation of the CC, the validation of the elections of representatives to the lower and upper houses of Parliament was decided by the elected representatives themselves. Charnay (1965) discusses the problems that this procedure entailed.

${ }^{9}$ Article 33 of 7 November 1958 Ordonnance n58-1067 portant Loi organique sur le Conseil Constitutionnel.
} 
than ten days after election day are also not accepted. Moreover, no one is eligible to appeal against the CC's decisions, neither to the CC itself nor to any other jurisdiction ${ }^{10}$.

When ruling on the validity of elections, the CC judges often rely on Article 38 of the 7 November 1958 Ordonnance n58-1067, which allows them to ignore irregularities if they wish to do so, following the legal principle of interpretation "de minimis non curat praetor" 11 : irregularities are considered irrelevant unless they change the outcome of the election. In practice, Article 38 has led CC judges to pay particular attention to the size of the vote differential between the two front-running candidates. They have thus upheld elections by arguing that the vote differential between the two leading candidates is sufficiently large for the irregularities to have no effect on the outcome of the electoral contest. In what follows, we examine whether the vote differential, which is a non-partisan and objective criterion, indeed explains whether elections are upheld or cancelled.

\section{The data}

In this study, we build a new dataset comprising the decisions of the $\mathrm{CC}$ in the 12 general elections and in the many by-elections to the lower house of Parliament between 1958 and 2005. In what follows, we discuss the construction of our variables, which are presented in Table 1. Descriptive statistics are given in Table 2.

\section{[Insert Table 1] [Insert Table 2]}

\subsection{The decisions of the CC}

From 4 December 1958 until 1 October 2005, the CC rendered 2229 decisions concerning the French parliamentary elections, including by-elections. Only 1102 concerned the validity of

\footnotetext{
${ }^{10}$ Article 62 of the French Constitution.

11 The judge does not deal with unimportant things.
} 
elections. The remaining 1127 decisions were not decisions on controverted elections but sanctions against candidates who failed to abide by the procedures concerning the elections of representatives. These decisions followed the recommendations of the governmental agency in charge of checking electoral spending, known as Commission Nationale des Comptes de Campagnes et de Financements Politiques (CNCCFP), which was created in 1990. The sanctioned candidates failed to provide a detailed account of their campaign spending or spent more than permitted.

Excluding the rulings that followed the CNCCFP's recommendations, as well as all the complaints that did not follow the appropriate procedures which were discussed in Section 2.2, we are left with a sample of 999 valid requests questioning the fairness of elections. The CC acknowledged the existence of irregularities in 411 of these 999 electoral races, but only cancelled 56 of them. We therefore create the following two qualitative variables: the Irregularities variable takes the value 1 if the CC acknowledged that irregularities occurred during a given election, and the Cancel variable takes the value 1 if the election is cancelled by the CC. Table 3 provides the number of valid requests reviewed by the CC between 1958 and 2005, as well as the number of elections with irregularities and the number of cancelled elections.

\section{[Insert Table 3]}

In Table 3, we notice that the CC only cancelled one of the 55 controverted by-elections whose validity it reviewed. This observation suggests using a restricted sample that includes the general elections but excludes the by-elections in order to obtain a robustness check on the regression results. The sample restricted to the sole 12 general elections contains 944 elections, including 388 elections with irregularities and 55 cancelled elections. 


\subsection{The CC judges}

Since the CC judges are appointed by politicians, we build several variables to assess the influence of politics on the CC's rulings. We create the Judges_appointed_RW variable to assess the share of judges appointed by mainstream right-wing politicians who sit on the CC's bench at the time of each ruling. We also take into account the shares of CC judges who are former leftwing and former right-wing politicians (Judges_Former_Left-wing_Politicians and Judges_Former_Right-wing_Politicians). These variables are of a political nature and should only be significant if the CC judges demonstrate partisanship when they rule on the controverted elections.

We also compute the share of judges who are jurists (Judges_Jurists), i.e., law professors and lawyers, as well as the share of former high-level civil servants (Judges_Civil_Servants). It may be hypothesized that judges with these two backgrounds may be more accurate in the application of election laws, and as such, non-partisan.

\subsection{The French polity}

The decisions of the judges may not only be explained by their background, but also by the situation of the French polity at the time of the rulings. We thus create the RW_government qualitative variable which equals 1 if the French government was dominated by mainstream right-wing parties.

In addition, it may be hypothesized that CC judges are more willing to cancel elections when the polity is divided between left-wing and right-wing parties ${ }^{12}$. Such a hypothesis follows Iaryczower et al. (2002), who argue that judges in constitutional courts are more likely to rule in

\footnotetext{
${ }^{12}$ Duverger (1986), among others, discusses how the constitutional arrangements of the Fifth Republic may entail a division of the polity between left-wing and right-wing parties.
} 
an independent manner when the polity is fragmented between opposing parties, since the politicians' ability to pressure the judges is then weakened. We thus create two qualitative variables to assess the extent of the polity's fragmentation when the CC judges rule on the controverted elections.

We create the Cohabitation variable, which takes the value 1 if the Prime Minister and the majority of the representatives in the lower house of Parliament on the one hand, and the President of the Republic on the other hand, do not belong to the same party. Such a situation, called cohabitation, occurred three times between 1958 and 2005: Socialist President François Mitterrand (1981-1995) had two right-wing Prime Ministers, Jacques Chirac (1986-1988) and Edouard Balladur (1993-1995), while President Jacques Chirac (1995-2007) had Socialist leader Lionel Jospin (1997-2002) as Prime Minister ${ }^{13}$.

Our second variable to assess the fragmentation of the polity focuses on the division between the upper and lower houses of the Parliament. We define the Senat variable as taking the value 1 each time the Sénat, the upper house of Parliament, opposed the policies of the government. Since the beginning of the Fifth French Republic in 1958, the upper house of Parliament has been dominated by right-wing parties. Therefore the upper house of Parliament opposed the policies of the government each time left-wing parties controlled a majority of the

\footnotetext{
${ }^{13}$ While the President of the French Republic's veto power does not allow him to unilaterally rescind legislation that he opposes, he still wields enough influence to partially disrupt the policies undertaken by his own Prime Minister. Indeed, the veto power of the French President is restricted by Article 10 of the French Constitution which states that the French President has to promulgate a law passed by the Parliament in the fifteen days that follow the vote. In this time period, he can ask the Parliament to re-discuss the law or file a request to the CC. But if the Parliament votes the same text or if the CC rules that the law is in conformity with the constitution, the President has to comply and promulgate the law.
} 
seats in the Assemblée Nationale, the lower house of Parliament (1981-1986, 1988-1993, 19972002). But the Sénat also opposed the policies of President Charles de Gaulle (1958-1969), since senators first opposed his handling of the war in Algeria, and then his successful drive to amend the French Constitution in order to provide for the election of the President of the Republic by the people in a general election.

\subsection{The characteristics of the elections}

We also collected information on the characteristics of the elections whose validity was questioned. We construct the Vote_Differential variable as the differential in the number of votes between the winner of the election and the candidate who came second. We expect to find a negative relationship between this variable and the annulment of elections. This is because the CC often justifies its decision to uphold the result of an election with irregularities by arguing that the vote differential between the two front-running candidates is sufficiently large for the irregularities not to have any influence on the outcome.

In addition, we noted if the person who filed a request to the CC was a candidate, in which case we took into account his political affiliation, or whether he was a voter living in the constituency (Request_Voter). We also take into account the political affiliations of the candidates who won the controverted elections.

We further included in our regressions several variables to control for the particular situations that result from the specificities of the French electoral system. Except in a couple of instances which we discuss below, the French electoral system has followed a two-round majority voting procedure with a single representative elected in each constituency. Candidates running in the French parliamentary elections can be elected in the first round if they obtain more than $50 \%$ of the votes (1_round). If not, a second round is held with all the candidates that gain a 
predetermined percentage of the votes. This threshold changed over the years. It was equal to $5 \%$ in 1958 and was progressively increased so that it amounted to $12.5 \%$ of the votes in 2002 . Hence there may be more than two candidates vying to be elected on the second round (More2candidates). But there were also elections with only one candidate in the second round (1candidate_2nd_round). This odd situation resulted from a couple of circumstances: (1) there were only two candidates eligible to run in the second round of the elections, and (2) both of them were either left-wing or right-wing. The candidate who obtained the smallest number of votes in the first round chose to withdraw his or her candidacy, and the remaining candidate was then elected with $100 \%$ of the votes ${ }^{14}$.

However, the two-round majority voting procedure was not always applied in French parliamentary elections. In 1958, the electoral system was different in Algeria, which was then a part of France with representatives elected to the lower and upper houses of Parliament. Algeria was divided into 18 constituencies where the electoral procedure followed a one-round party list majority rule. The list which would get the highest number of votes would have all its candidates elected in Parliament. All these elections are singled out by the qualitative variable Algeria.

In addition, in 1986, all the French representatives were elected in a one-round party-list election under a proportional voting system (1986_elections). From a political perspective, the 1986 elections were unusual and turned out to be a major success for the far-right Front National (FN - National Front). While FN candidates found it hard to win seats in French parliamentary elections because of the two-round run-off system, the proportional system provided them in 1986 with 35 out of 577 seats. Therefore, in order to assess the robustness of our results, we run

\footnotetext{
${ }^{14}$ In that instance, we computed the Vote_Differential variable as the difference in the number of votes between the two candidates who received the highest number of votes in the first round.
} 
regressions with and without the 22 parliamentary elections whose validity was challenged in 1986. As an additional robustness check, we test whether the CC judges treat far-right candidates differently by running supplementary regressions with the Vote_Differential_Winner_Far_Right variable, which assesses the vote differential between the two-front running candidates in elections won by far-right politicians.

\section{Methodology}

In order to identify the characteristics of the elections which the CC cancelled, our empirical approach takes into account the two stages of the review process undertaken by the CC. First, when a complaint questioning the validity of an election is filed, the CC rules whether an irregularity occurred. Second, if the CC acknowledges the existence of an irregularity, it may decide to invalidate the election.

Such a procedure suggests using Heckman (1979)'s two-step approach ${ }^{15}$. While the first step estimates the probability of irregularity in the sample of controverted elections, the second step estimates the probability of cancellation in the sample of electoral races with irregularities.

In the first step of Heckman’s (1979) estimation procedure, a probit model is used to obtain the probability that the $\mathrm{CC}$ acknowledges the existence of irregularities in an election

$$
\text { Irregularities }=\gamma_{0}+X^{\prime} \gamma+\eta
$$

where the qualitative variable Irregularities takes the value 1 if the CC judges find irregularities in a given election, and $X$ is the vector of regressors. From the estimated parameters of the probit model, we calculate the estimated hazard rate $\lambda$ which is equal to

\footnotetext{
${ }^{15}$ The results we obtained with the Heckman (1979)'s two-step approach are robust to other estimation methods: we notably experimented with Tobit and probit models, as well as panel data specifications in order to take into account possible time- and constituency-specific effects in the CC's rulings.
} 


$$
\lambda=\frac{f(X \cdot \gamma)}{F(X \cdot \gamma)}
$$

where $\mathrm{X}$ and $\gamma$ are respectively the vector of regressors and the vector of parameters in equation

(1), $f()$ is the probability density function of a standard normal variable, and $F()$ the corresponding cumulative distribution function.

We can then use $\lambda$ to normalize the mean of the true error term to zero, and get consistent estimators in the second step of the estimation

$$
\text { Cancel }=\phi_{0}+X_{1}^{\prime} \phi_{1}+X_{2}^{\prime} \phi_{2}+\sigma \cdot \hat{\lambda}+v
$$

where Cancel equals 1 if the CC cancelled the election and 0 otherwise, $X_{1}$ is a vector of variables containing information on the CC judges, $X_{2}$ is a vector of data on the characteristics of the elections and $\sigma$ is the standard deviation of the true error term $\varepsilon$.

If the associated coefficient to the estimated hazard rate $\lambda$ is not statistically significant, our specification is not affected by a selection bias. In other words, our specification correctly distinguishes between the characteristics of the elections where the CC acknowledges the existence of irregularities and the features of the elections that the CC cancels.

\section{Results}

This section analyzes the results of our regressions. Table 4 displays the estimation results on our main sample, which comprises all the decisions rendered by the CC judges between 1958 and 2005. Furthermore, Tables 5, 6 and 7 provide additional regressions to control for the robustness of the results in Table 4 . Table 5 shows the decisions handed out in the election years when a majority of the CC judges were appointed by mainstream right-wing politicians, i.e., excluding the elections held between 1988 and 2001. Table 6 provides a robustness check on the bias of the CC judges against far-right candidates by including the 
Vote_Differential_Winner_Far_Right variable, which assesses the vote differential between the two-front running candidates in elections won by far-right candidates. In addition, Table 7 analyses the characteristics of the CC's rulings when right-wing governments were in power, i.e., between 1958 and 1981, 1986 and 1988, 1993 and 1997, and between 2002 and 2005 (the last year in our sample). ${ }^{16}$

In all the Tables, we distinguish between the general and the by-elections, as well as between the 1986 and the other parliamentary elections. We also note that the hazard rate $\lambda$ is insignificant in all the regressions: the estimation of the characteristics of the cancelled elections is therefore not affected by a selection bias.

[Insert Table 4] [Insert Table 5] [Insert Table 6]

\subsection{The characteristics of elections with irregularities}

In order to determine the characteristics of elections where the CC acknowledged the existence of irregularities, we analyze the first stage of Heckman (1979)'s two-step regression which is shown in the lower part of Tables 4, 5 and 6. The results suggest that the judges' background partially explains their willingness to acknowledge irregularities. However, the judges do not display partisanship when they rule that irregularities occurred during an electoral campaign.

More specifically, Tables 4 and 5 show that the background of the CC judges has an impact on the probability that irregularities may be found in an election. Table 4 indicates that less irregularities are found when more jurists sit on the CC's bench. But when more civil servants sit on the CC's bench, Table 5 shows that more irregularities are found. However, both results should be viewed with caution as they are not robust across all our specifications. In addition, we

\footnotetext{
${ }^{16}$ Regressions analyzing the CC’s decisions under left-wing governments are available upon request.
} 
observe in columns 3 and 4 of Table 4 that more irregularities are found when a higher share of judges appointed by right-wing politicians sit on the CC's bench, but this result is also not robust in all our regressions. This observation may nevertheless suggest that judges appointed by rightwing politicians are stricter in the application of election laws.

Still, the results in Tables 4 and 5 indicate that the CC judges treat identically the requests of politicians from different parties and do not display any partisan bias in the first stage of the election review process. Indeed, our regressions show that the CC judges acknowledge the existence of irregularities in the elections whose validity is challenged by mainstream left-wing, mainstream right-wing and far-right candidates.

In addition, the Request_Voter variable is never significant in our regressions, thus showing that CC does not find any irregularity in the elections whose validity is questioned by voters. This result suggests that most voters do not usually have any good reason to dispute the legality of the elections and the CC renders a judgment of nonsuit against their requests. It may also explain why the CC does not acknowledge the existence of irregularities in elections where there are more than two candidates in the second round, as can be seen in Columns 1 and 2 of Table 4. Voters mistakenly believe that elections with more than two candidates in the second round are irregular but they are not.

As such, our results suggest that the CC judges rule sincerely when they acknowledge the existence of irregularities, even though they are appointed by politicians and probably have political ideas of their own. However, when the judges acknowledge irregularities in an election, they do not necessarily annul it because they rely upon the legal principle of interpretation "de minimas non curat praetor", as we discussed above. As a result, the crucial element in the 
annulment of an election is the CC judges' assessment of the gravity of the irregularities. In what follows, we examine whether such an assessment is influenced by political considerations.

\subsection{The characteristics of cancelled elections}

The upper parts of Tables 4, 5 and 6 present the results of the second stage of Heckman's two-step method where we estimate the probability that an election is cancelled once the CC has acknowledged the existence of irregularities. In all the Tables, our results are robust to the different specifications and samples: the apolitical factors are shown to hardly have an effect on the CC's decisions while the political factors are seen to have a salient impact.

Indeed, only one apolitical factor consistently explains the annulment of elections: the proportional voting system that was adopted in the 1986 parliamentary elections. As can be seen in Table 3, this voting system led to a reduction in the number of constituencies, from 577 to 104. Fewer constituencies meant that fewer elections could be controverted: only 22 requests were filed in 1986, compared to 84.2 on average in the 11 other general elections. Out of these 22 controverted elections, two elections were cancelled by the CC, i.e., $9 \%$ of the requests led to cancellations. This is clearly a higher percentage than in the other 11 general elections, where on average, only $6.5 \%$ of the requests led to annulments. As such, we can explain the significance of the apolitical variable 1986_elections by the low number of electoral contests in the 1986 parliamentary elections.

More generally, the lack of significance of apolitical variables in our regressions is particularly noteworthy for the Vote_Differential variable, which assesses the vote differential between the two-front running candidates in a parliamentary election. Indeed, this observation suggests that the CC judges do not take into account this objective and non-partisan criterion to cancel elections, unlike what they write in their rulings. 
As a matter of fact, the only variables which are significant across all our regressions in explaining the characteristics of the cancelled elections are of a political nature: these are the variables which pertain to the party affiliation of the elected candidates. We find in all the Tables that an election is more likely to be annulled if the elected candidate hails from the far-right. This result is statistically significant at the $1 \%$-level in all our specifications; it holds whether or not we include in our sample the 1986 parliamentary elections, which were a major success for the far-right. Hence, the minor irregularities that far-right candidates commit are interpreted by the CC judges in such a way that their elections are cancelled. Conversely, the victories of candidates from the communist party and from the mainstream right-wing parties are likely to be upheld, whether or not there is a majority of judges appointed by right-wing politicians sitting on the CC's bench. Thus, the irregularities which communist and mainstream right-wing candidates commit, and which are detrimental to the electoral success of far-right candidates, never lead to the annulment of elections ${ }^{17}$.

It may be argued that far-right candidates commit more irregularities in tight electoral races than the candidates from the other parties, and consequently, that the judges are warranted in canceling their elections. Table 6 proves that such an argument is incorrect by showing that an objective criterion like the vote differential in elections won by far-right candidates, which is assessed by the Vote_Differential_Winner_Far_Right variable, does not explain the annulment of the elections. ${ }^{18}$

\footnotetext{
${ }^{17}$ We illustrate this point by providing excerpts of CC decisions 97/2101 and 97/2209.

${ }^{18}$ Additional regressions that are available upon request show that the vote differential is never significant in explaining the annulment of the elections, whatever the political affiliation of the winner.
} 
Hence our results demonstrate that the decisions of the CC judges are politically motivated. At the same time, they show also that the CC judges are independent from the ruling party as can be seen in Tables 4 and 5 from the lack of significance of the variables which we use to assess political circumstances (RW_government, Senat and Cohabitation). In addition, the CC judges who are appointed by mainstream left-wing (respectively, right-wing) politicians are not biased against mainstream right-wing (left-wing) candidates. Moreover, the controverted elections of communist candidates are usually upheld, even though no communist politician has ever appointed a CC judge. ${ }^{19}$

These results can only be explained if we take into account the CC judges' self-interest in relation to the polity. Since 1958, mainstream left-wing and right-wing politicians have usually been senior members of government; communist politicians were also junior partners in governments led by the mainstream left-wing parties on two occasions (1981-1983 and 19972002). In other words, politicians from the communist, mainstream left-wing and mainstream right-wing parties may not win a given general parliamentary election but they may win the next one. CC judges would therefore be ill-advised to rule in a partisan manner against politicians who may be in power after the next election. As a result, CC judges do not cancel the elections of communist and mainstream right-wing politicians, unless they commit irregularities that are too obvious ${ }^{20}$.

\footnotetext{
${ }^{19}$ These results are shown to be robust in Table 7 where we restrict the sample to the sole decisions rendered under right-wing governments. Regressions analyzing the CC's decisions under left-wing governments, which are available upon request, show similar results.

${ }^{20}$ However, it is not clear what an obvious irregularity is for the CC judges, as can be seen from the excerpts of decision 97-2113/2119/2146/2154/2234/2235/2242/2243 that are given in the Appendix. In this ruling, the CC judges acknowledge that mainstream right-wing politician and incumbent Paris mayor Jean Tibéri tampered with the
} 
A similar combination of judicial independence, partisanship and self-interest also explains the CC judges' behavior vis-à-vis far-right candidates. Since all the CC judges have been nominated by either mainstream left-wing or mainstream right-wing politicians, who oppose the far-right, it is not surprising that they issue rulings which are detrimental to far-right candidates. But self-interested CC judges also know that since 1958, far-right politicians have never obtained a sufficiently important number of seats in the lower house of Parliament to become junior partners in a governmental coalition, let alone to lead a government. Thus the far-right's inability to be a powerful force in French politics explains why CC judges have been able to rule against far-right candidates in a partisan manner: they know that they are unlikely to face retaliation from far-right politicians in the future.

\section{Conclusion}

This paper assesses the independence of the Conseil Constitutionnel, France's supreme constitutional court, by focusing on its rulings on the validity of elections to the lower house of Parliament. We analyze the decisions of the CC between 1958 and 2005 over 999 elections whose outcome was challenged by candidates or voters.

Our estimations show that the CC's decisions are not based on legal, but on political, considerations. For instance, the vote differential between the two front-running candidates is not a criterion that influences the CC's decisions to cancel elections, contrary to what the CC judges write in their rulings. However, we also observe that the judges do not display narrow-minded partisanship. They do not systematically back candidates from the party of the politicians who appointed them. They also display some form of independence vis-à-vis the government: both

poll registers so as to increase his vote share. However, they considered that this interference did not affect the outcome of the elections. 
winners and losers of controverted elections do not benefit from belonging to the ruling party when the CC judges issue their rulings.

Still, we find that the elections of far-right candidates are often cancelled, even though there is not any objective criterion to warrant such annulments. This result can easily be explained by the CC judges' political biases and self-interest. On the one hand, CC judges certainly share the views of the politicians who appointed them and who were all opponents of the far-right. On the other hand, CC judges know that far-right politicians do not have the means to significantly threaten their independence and curb their power.

All in all, this paper suggests that a constitutional court whose judges are nominated by politicians may not be the optimal mechanism to deliver an unbiased assessment of the validity of elections. It is however unclear which institutional system would provide non-partisan rulings on controverted elections. A normative analysis of this issue may therefore be the subject of further research.

\section{Appendix}

In this Appendix, we provide excerpts of judgments rendered by the CC on the validity of three parliamentary elections held in 1997 (all translations are ours). In the first decision (972181), a candidate of the far-right Front National contested the validity of the elections, but his request was rejected on the grounds that the irregularities that were committed could not have had an impact on the outcome of the election.

In the second decision (97-2209), Front National candidate Jean-Marie Le Chevallier won the parliamentary election in Toulon. However, the CC judges considered that he committed irregularities which justified the cancellation of his election. In particular, they argued that JeanMarie Le Chevallier had spent more than what campaign spending limits in parliamentary 
elections allowed him, even though he contented that the litigious spending was on the one hand paid by his party, and was on the other hand not related to his electoral campaign (See France Ministère de l'intérieur (1997) on campaign spending limits in the 1997 French parliamentary elections). In any case, the CC judges' interpretation of the law in decision 97-2209 was very unfavorable to Jean-Marie Le Chevallier.

It was however very favorable to mainstream right-wing politician Jean Tibéri, who was the then mayor of Paris, as well as the political protégé of Jacques Chirac, the former mayor of Paris and the then President of the French Republic. Indeed, in decision 972113/2119/2146/2154/2234/2235/2242/2243, the CC judges validated Jean Tibéri’s election, even though he tampered with poll registers. They argued that the vote differential between the candidates in the second round of the election was higher that the presumed number of fraudulent voters. It may be suspected that the CC judges would have rendered a different judgment if Jean Tibéri had been a far-right candidate without a powerful political mentor.

\section{A.1. Excerpt of decision 97-2181}

[Front National candidate] Mr. Chauvet argues that on the first round of the elections held on 25 May 1997, two persons entered polling station number 6 in Fleury-les-Aubrais and stole all the voting papers with his name, thus preventing him from gaining access to the second round;

These events however occurred 40 minutes before the polls ended; Mr. Chauvet obtained 80 votes in this polling station; therefore this incident, as blameworthy as it may be, did not prevent him from obtaining the 214 votes which he needed to run in the second round; (...). 


\section{A.2. Excerpt of decision $97-2209$}

(....) First, [Front National candidate] Mr. Le Chevallier declared that he spent 161,696 Francs for his own campaign, instead of having his financial agent pay for this amount; but while the candidate can pay some of his campaign spending, this can only be tolerated if this spending remains limited; in contrast, Mr. Le Chevallier paid $60 \%$ of his total campaign spending and therefore violated the second paragraph of article L. 52-4 of the electoral code;

Second, Mr. Le Chevallier benefited for his campaign from services by the "Management Center of the National Front”, which included leaflets, posters, badges, videos (...), for an amount of 92,005 Francs; (...)

Third, the bimestrial review "Le Toulonnais", which is the official bulletin of the city of Toulon, which has been headed by Mr. Le Chevallier since 1995, published its issue 26 on 20 May 1997, i.e., five days before the first round of the election. Seven of the 16 pages of that issue, including the cover with the title "A crushing report", gave excerpts of governmental reports on the management of the city of Toulon (...) during the 1988-1994 period; this issue must be regarded as an instrument of propaganda since it dealt with one of the major themes of Mr. Le Chevallier's campaign against [socialist candidate] Mr. Colin; (...); the amount of these seven pages $(\ldots)$ is 26,088 Francs, $(\ldots)$

Mr. Colin is therefore correct in asserting that Mr. Le Chevallier's campaign spending account is faulty $(\ldots)$

\section{A.3. Excerpt of decision 97-2113/2119/2146/2154/2234/2235/2242/2243}

(....) On the existence of a maneuver in the poll books in the fifth district [of Paris]:

(...) It results from the investigation, and notably from the Conseil Constitutionel's inquiry, that, in the fifth district [of Paris], a high number of voters were registered as living in public 
housing owned by the municipality of Paris, even though they are unknown to the agencies which manage these buildings; in some cases, it turns out that these individuals actually lived in public housing in other Parisian districts; the investigation also showed that some voters resided in buildings that were fictitious or unable to accommodate the number of registered voters, and that some voters resided in flats that are owned by the mayor's office of the fifth district of Paris; $(\ldots)$

It also results from the inquiry that several hundreds of voter ids did not arrive to their addressees, even though the latter did not change flats (...);

All these serious and numerous deeds inside the same district, provide evidence that there was a maneuver in the organization of the poll registers;

However, it results from the inquiry that the number of voters whose registration may be fraudulent and who voted in the second round of the election is perceptibly lower than the vote differential between the candidates that amounts to 2725 votes; this maneuver might therefore be blameworthy, but it did not change the outcome of the elections; (....). 


\section{References}

Berkowitz, D., Clay, K., 2005. American Civil Law Origins: Implications for State Constitutions, American Law and Economics Review 7 (1), 62-84.

Berkowitz, D., Clay, K., 2006. The Effect of Judicial Independence on Courts: Evidence from the American States, Journal of Legal Studies 35(2), 399-400.

Bradbury, J.C., Crain W.M., 2001. Legislative Organization and Government Spending: CrossCountry Evidence, Journal of Public Economics 82 (3), 309-325.

Del Rossi A, Inman R., 1999. Changing the Price of Pork: the Impact of Local Cost Sharing on Legislator’s Demands for Distributive Public Goods, Journal of Public Economics 71, 247273.

Charnay, J.-P., 1965. Les Scrutins Politiques en France de 1815 a 1962: Contestations et Invalidations, Paris: Collection Cahiers de la Fondation Nationale des Sciences Politiques, Armand Collin.

Duverger, M., 1986, Bréviaire de la Cohabitation, Paris: Presses Universitaires de France.

France - Ministère de l’intérieur, 1997. Financement et plafonnement des dépenses électorales. Circulaire du 22 avril 1997, Paris: Imprimerie Nationale.

Franck, R., 2009. Judicial Independence under a Divided Polity: a Study of the Rulings of the French Constitutional Court, 1959-2006, Journal of Law, Economics and Organization, forthcoming.

Gely, R., Spiller, P.T., 1990. A Rational Choice Theory of Supreme Court Statutory Decisions with Applications to the State Farm and the Grove City Cases, Journal of Law, Economics and Organization 6, 263-300. 
Gely, R., Spiller, P.T., 1992. The Political Economy of Supreme Court Constitutional Decisions: the Case of Roosevelt's Court-Packing Plan, International Review of Law and Economics 12, 45-67.

Gilligan, T.W., Matsusaka, J.G., 2001. Fiscal policy, legislature size and political parties: evidence from state and local governments in the first half of the $20^{\text {th }}$ Century, National Tax Journal 54 (1), 57-82.

Giordano, A., 2006. Mexico’s Presidential Swindle, New Left Review, September-October, 5-27.

Hanssen, F.A., 2004. Is There a Politically Optimal Level of Judicial Independence?, American Economic Review 94 (3), 712-729.

Hasen, R.L., 2004. A Critical Guide to Bush v. Gore Scholarship, Annual Review of Political Science 7, 297-313.

Heckman, J.J., 1979. Sample Selection Bias as a Specification Error, Econometrica 47, 153-161. Iaryczower, M., Spiller, P.T., Tommasi M., 2002, Judicial independence in unstable environments, Argentina 1935-1998, American Journal of Political Science 46 (4), 699716.

Lamoreux, N.R., Rosenthal, J-L., 2005, Legal Regime and Contractual Flexibility: A Comparison of Business's Organizational Choices in France and the United States during the Era of Industrialization, American Law and Economics Review 7(1), 28-61.

La Porta, R., Lopez-de-Silanes, F., Shleifer, A., 2008, The Economic Consequences of Legal Origins, Journal of Economic Literature 46 (2), 285-332.

La Porta, R., Lopez-de-Silanes, F., Shleifer, A., Vishny, R.W., 1997. Legal Determinants of External Finance, Journal of Finance 52, 1131-1150. 
La Porta, R., Lopez-de-Silanes, F., Shleifer, A., Vishny, R.W., 1998. Law and Finance, Journal of Political Economy 106, 1113-1155.

La Porta, R., Lopez-de-Silanes, F., Shleifer, A., Vishny, R.W., 1999. The Quality of Government, Journal of law, Economics and Organization 15 (1), 222-279.

Ramseyer, J.M, Rasmusen E.B., 1997. Judicial independence in a civil law regime: the evidence from Japan, Journal of law, Economics and Organization 13 (2), 259-286.

Ramseyer, J.M., Rasmusen E.B., 2001. Why are Japanese Judges so Conservative in Politically Charged Cases?, American Political Science Review 95 (2), 331-344.

Rémond, R., 1982. Les Droites en France, $4^{\text {th }}$ edition, Paris: Aubier-Montaigne.

Segal, J.A., Spaeth, H.J., 2002. The Supreme Court and the Attitudinal Model Revisited. Cambridge, UK: Cambridge University Press.

Spiller, P.T., Gely, R., 1992, Congressional Control or Judicial Independence: The Determinants of U.S. Supreme Court Labor-Relations Decisions, 1949-1988, The RAND Journal of Economics 23 (4), 463-492.

Stone, A., 1992. The Birth of Judicial Politics in France. Oxford: Oxford University Press. 
Table 1. Lists of variables

\section{Dependent variables}

Cancel

Irregularities

\section{Explanatory variables}

The CC judges

Judges_Former_Left-wing_Politicians Judges_Former_Right-wing_Politicians Judges_Civil_servants

Judges_Jurists

Judges_appointed_RW

The French polity

Senat

Cohabitation

RW_government
$=1$ if the election is cancelled by the CC; 0 otherwise

$=1$ if the CC acknowledged that irregularities occurred during the election; 0 otherwise

Share of former left-wing politicians in the CC

Share of former right-wing politicians in the CC

Share of former high-level civil servants in the CC

Share of judges with a specialization in law, i.e., lawyers, law professors

Share of judges nominated by right-wing politicians

$=1$ if the President of the Republic and the Prime Minister are of opposing parties; 0 otherwise

$=1$ if the upper house of Parliament opposes the policies of the Government; 0 otherwise

$=1$ if the Government is right-wing; 0 otherwise

The characteristics of the controverted elections Vote_Differential

Difference in the number of votes between the winner of the election and the candidate who came second

Vote_Differential_Winner_Far_Right

Difference in the number of votes between the winner of the election and the candidate who came second, when the winner is a far-right candidate

1986_Elections

Algeria

$=1$ for the 1986 parliamentary election; 0 otherwise

=1 for elections held in Algeria in 1958 under a one-round party list voting system; 0 otherwise

$=1$ if the election was settled in one round; 0 otherwise

$=1$ if more than two candidates were present on the second round of the elections; 0 otherwise

More2candidates

1candidate_2nd_round

$=1$ if only one candidate was present on the second round of the election; 0 otherwise

The authors of the requests

Request_Voter

Request_Far_Left

Request_Com

$=1$ if the election was questioned by a voter in the constituency, not by a candidate; 0 otherwise

$=1$ if the election was questioned by a far-left candidate; 0 otherwise

$=1$ if the election was questioned by a candidate from the French Communist Party; 0 otherwise 
Request_Main_Left

Request_LW

Request_Green

Request_Independent_Ecologist

Request_Independent

Request_GE

Request_RW

Request_Main_Right

Request_Far_Right

The winners of the controverted elections

Winner_Election_Com

Winner_Election_Green

Winner_Election_Main_Left

Winner_Election_LW

Winner_Election_Independent

Winner_Election_RW

Winner_Election_Main_Right

Winner Election Far Right
$=1$ if the election was questioned by a mainstream left-wing (social-democrat) candidate; 0 otherwise $=1$ if the election was questioned by a left-wing candidate not affiliated with any major left-wing party; 0 otherwise

$=1$ if the election was questioned by a candidate from the left-wing ecologist "Green" party; 0 otherwise

$=1$ if the election was questioned by a independent/apolitical ecologist candidate; 0 otherwise

$=1$ if the election was questioned by an independent/apolitical candidate; 0 otherwise

$=1$ if the election was questioned by a candidate from the right-wing ecologist "Generation Ecologie" party; 0 otherwise

$=1$ if the election was questioned by a right-wing candidate not affiliated with any major right-wing party; 0 otherwise

$=1$ if the election was questioned by a candidate from the mainstream right-wing parties; 0 otherwise

$=1$ if the election was questioned by a far-right candidate; 0 otherwise

Number of candidates from the French Communist Party elected in the constituency

Number of candidates from the left-wing ecologist "Green" Party elected in the constituency

Number of candidates from the mainstream left-wing (social-democrat) party elected in the constituency

Number of left-wing candidates not affiliated with a major left-wing party elected in the constituency

Number of independent candidates elected in the constituency

Number of right-wing candidates not affiliated with a right-wing party elected in the constituency

Number of candidates from the mainstream right-wing parties elected in the constituency

Number of candidates from far-right parties elected in the constituency

Note: In 1958 in Algeria, as well as in the 1986 parliamentary elections throughout France, the principle of a single-member representative in each constituency was not applied. Instead, several representatives were elected in the constituency. Consequently, the variables Winner_Election_Com, Winner_Election_Green,

Winner_Election_Far_Right are not dummy variables. 
Table 2. Descriptive statistics

\section{Dependent variables}

Cancel

Irregularities
Mean Std. Dev. Min Max

$\begin{array}{llll}0.056 & 0.230 & 0 & 1\end{array}$

$\begin{array}{llll}0.411 & 0.492 & 0 & 1\end{array}$

\section{Explanatory variables}

The CC judges

Judges_Former_Left-wing_Politicians

Judges_Former_Right-wing_Politicians

Judges_Civil_servants

Judges_Jurists

Judges_appointed_RW

0.204

0.191

0.117

0.519

0.618

0.093

0.155

0.078

0.122

0.170

0.577

0.311

0.806

0.494

0.463

0.396

RW_government

$\begin{array}{cc}0 & 0.444 \\ 0 & 0.444 \\ 0 & 0.222 \\ 0.111 & 0.778 \\ 0.333 & 1\end{array}$

1

1

1

1

1

The characteristics of the controverted elections

Vote Differential

6521.10

9166.11

Vote_Differential_Winner_Far_Right

144.94

1968.33

1986_Elections

0.022

0.147

Algeria

0.016

0.126

1_round

0.113

0.317

0.145

0.352

1candidate_2nd_round

0.020

0.140

0.348

0.010

0.477

0.052

0.100

Request_Voter
Request_Far_Left

0.138

0.222

Request_Main_Left

Request_LW

0.042

0.345

Request_Green

0.034

0.201

Request_Independent_Ecologist

0.003

0.181

Request_Independent

0.070

0.055

0.005

0.255

Request_GE

0.052

0.071

Request_RW

0.254

0.222

0.436

0.126

0.332

$0.116 \quad 0.339$

0.002

0.045

0.321

0.635

Winner_Election_Main_Left

0.020

0.140

Winner_Election_Independent

0.024

0.188

Winner_Election_RW

0.033

0.210

0.611

0.644

Winner_Election_Far_Right

0.095 
Table 3. Number of valid requests judged by the CC, of elections with acknowledged irregularities and of cancelled elections.

\begin{tabular}{|c|c|c|c|c|c|c|}
\hline Year & Type of elections & Seats & Electoral contests & $\begin{array}{l}\text { Valid requests to } \\
\text { the CC }\end{array}$ & $\begin{array}{l}\text { Elections with } \\
\text { irregularities }\end{array}$ & $\begin{array}{l}\text { Cancelled } \\
\text { elections }\end{array}$ \\
\hline 1958 & General elections & 576 & 503 & 106 & 39 & 5 \\
\hline 1962 & General elections & 482 & 482 & 63 & 32 & 7 \\
\hline 1963 & By-elections & 5 & 5 & 5 & 1 & 0 \\
\hline 1967 & General elections & 486 & 486 & 132 & 27 & 4 \\
\hline 1968 & General elections & 487 & 487 & 46 & 25 & 2 \\
\hline 1969 & By-elections & 1 & 1 & 1 & 0 & 0 \\
\hline 1973 & General elections & 490 & 490 & 38 & 18 & 2 \\
\hline 1975 & By-elections & 1 & 1 & 1 & 0 & 0 \\
\hline 1976 & By-elections & 2 & 2 & 2 & 0 & 0 \\
\hline 1978 & General elections & 491 & 491 & 48 & 20 & 5 \\
\hline 1980 & By-elections & 2 & 2 & 2 & 0 & 0 \\
\hline 1981 & General elections & 577 & 577 & 50 & 22 & 4 \\
\hline 1982 & By-elections & 1 & 1 & 1 & 0 & 0 \\
\hline 1984 & By-elections & 1 & 1 & 1 & 0 & 0 \\
\hline 1986 & General elections & 577 & 104 & 22 & 5 & 2 \\
\hline 1988 & General elections & 577 & 577 & 70 & 36 & 7 \\
\hline 1989 & By-elections & 4 & 4 & 4 & 1 & 0 \\
\hline 1990 & By-elections & 1 & 1 & 1 & 1 & 0 \\
\hline 1991 & By-elections & 1 & 1 & 1 & 0 & 0 \\
\hline 1992 & By-elections & 1 & 1 & 1 & 0 & 0 \\
\hline 1993 & General elections & 577 & 577 & 142 & 74 & 6 \\
\hline 1994 & By-elections & 2 & 2 & 2 & 1 & 0 \\
\hline 1995 & By-elections & 11 & 11 & 11 & 4 & 0 \\
\hline 1996 & By-elections & 9 & 9 & 9 & 3 & 0 \\
\hline 1997 & General elections & 577 & 577 & 135 & 60 & 4 \\
\hline 1998 & By-elections & 4 & 4 & 4 & 4 & 1 \\
\hline 1999 & By-elections & 2 & 2 & 2 & 1 & 0 \\
\hline 2000 & By-elections & 2 & 2 & 2 & 1 & 0 \\
\hline 2001 & By-elections & 1 & 1 & 1 & 0 & 0 \\
\hline 2002 & General elections & 577 & 577 & 95 & 35 & 7 \\
\hline 2003 & By-elections & 1 & 1 & 1 & 1 & 0 \\
\hline
\end{tabular}

Note:

- In the 1958 and in 1986 elections, the number of seats is higher than the number of elections. This is because in 1958, the members of parliament from Algeria were elected on party lists while in 1986, all the members of parliament were elected on party lists. 
Table 4. Characteristics of the irregular and cancelled elections judged by the Conseil Constitutionnel, 1958-2005

\begin{tabular}{|c|c|c|c|c|c|}
\hline \multirow{13}{*}{$\begin{array}{l}\text { The characteristics } \\
\text { of the controverted } \\
\text { elections }\end{array}$} & & (1) & (2) & (3) & (4) \\
\hline & \multirow[t]{2}{*}{ Vote_Differential } & $-2.13 E-06$ & $-1.32 \mathrm{E}-06$ & $-2.09 \mathrm{E}-06$ & $-1.28 \mathrm{E}-06$ \\
\hline & & [1.99E-6] & [1.97E-6] & [1.98E-6] & [1.97E-6] \\
\hline & \multirow[t]{2}{*}{ 1986_elections } & 0.478 & & 0.601 & \\
\hline & & [0.311] & & {$[0.289]^{* *}$} & \\
\hline & \multirow[t]{2}{*}{ Algeria } & 0.078 & -0.305 & 0.145 & -0.2 \\
\hline & & [0.195] & {$[0.288]$} & {$[0.197]$} & {$[0.296]$} \\
\hline & \multirow{2}{*}{ 1_round } & -0.016 & -0.003 & 0 & 0.012 \\
\hline & & {$[0.055]$} & {$[0.055]$} & {$[0.056]$} & {$[0.056]$} \\
\hline & \multirow[t]{2}{*}{ More2candidates } & -0.094 & -0.074 & -0.084 & -0.065 \\
\hline & & {$[0.055]^{*}$} & {$[0.055]$} & {$[0.055]$} & {$[0.054]$} \\
\hline & \multirow[t]{2}{*}{ 1candidate_2nd_round } & 0.169 & 0.157 & 0.181 & 0.171 \\
\hline & & {$[0.122]$} & [0.121] & [0.122] & {$[0.122]$} \\
\hline \multirow{16}{*}{$\begin{array}{l}\text { Winners of the } \\
\text { controverted elections }\end{array}$} & \multirow[t]{2}{*}{ Winner_Election_Com } & -0.184 & 0.024 & -0.209 & -0.018 \\
\hline & & {$[0.067]^{* * *}$} & [0.118] & {$[0.067]^{* * *}$} & [0.121] \\
\hline & \multirow[t]{2}{*}{ Winner_Election_Green } & -0.307 & -0.115 & -0.332 & -0.156 \\
\hline & & [0.333] & [0.345] & [0.331] & [0.345] \\
\hline & \multirow[t]{2}{*}{ Winner_Election_Main_Left } & -0.074 & 0.1 & -0.09 & 0.067 \\
\hline & & {$[0.050]$} & {$[0.108]$} & {$[0.051]^{*}$} & {$[0.112]$} \\
\hline & \multirow[t]{2}{*}{ Winner_Election_LW } & -0.011 & 0.169 & 0.019 & 0.182 \\
\hline & & [0.115] & {$[0.148]$} & [0.124] & {$[0.158]$} \\
\hline & \multirow[t]{2}{*}{ Winner_Election_Independent } & -0.12 & 0.038 & -0.119 & 0.022 \\
\hline & & {$[0.083]$} & [0.117] & {$[0.083]$} & {$[0.120]$} \\
\hline & \multirow[t]{2}{*}{ Winner_Election_RW } & -0.001 & 0.052 & 0.002 & 0.036 \\
\hline & & {$[0.083]$} & [0.145] & {$[0.082]$} & {$[0.147]$} \\
\hline & \multirow{2}{*}{ Winner_Election_Main_Right } & -0.125 & 0.068 & -0.124 & 0.054 \\
\hline & & {$[0.049]^{* *}$} & [0.109] & {$[0.049]^{* *}$} & [0.113] \\
\hline & \multirow{2}{*}{ Winner_Election_Far_Right } & 0.618 & 0.887 & 0.634 & 0.887 \\
\hline & & {$[0.172]^{* * *}$} & {$[0.203]^{* * *}$} & {$[0.171]^{* * *}$} & {$[0.203]^{* * *}$} \\
\hline \multirow[t]{10}{*}{ The CC judges } & \multirow[t]{2}{*}{ Judges_Former Left-wing Politicians } & 0.144 & 0.179 & 0.087 & 0.072 \\
\hline & & [0.349] & [0.347] & [0.322] & {$[0.320]$} \\
\hline & \multirow[t]{2}{*}{ Judges_Former Right-wing Politicians } & 0.36 & 0.312 & 0.208 & 0.193 \\
\hline & & {$[0.386]$} & {$[0.384]$} & {$[0.208]$} & {$[0.207]$} \\
\hline & \multirow[t]{2}{*}{ Judges_Civil servants } & -0.077 & -0.185 & -0.057 & -0.115 \\
\hline & & [0.381] & [0.379] & {$[0.236]$} & [0.235] \\
\hline & \multirow[t]{2}{*}{ Judges_Jurists } & 0.034 & 0.103 & -0.069 & -0.077 \\
\hline & & [0.395] & [0.394] & {$[0.171]$} & {$[0.170]$} \\
\hline & \multirow[t]{2}{*}{ Judges_appointed_RW } & 0.324 & 0.411 & -0.41 & -0.363 \\
\hline & & {$[0.455]$} & {$[0.455]$} & {$[0.838]$} & {$[0.835]$} \\
\hline \multirow[t]{8}{*}{ The French polity } & Senat & 0.11 & 0.108 & & \\
\hline & & {$[0.067]$} & {$[0.066]$} & & \\
\hline & Cohabitation & 0.089 & 0.095 & & \\
\hline & & [0.099] & [0.098] & & \\
\hline & RW_government & 0.087 & 0.081 & & \\
\hline & & {$[0.088]$} & {$[0.088]$} & & \\
\hline & Constant & -0.157 & -0.417 & 0.309 & 0.156 \\
\hline & & {$[0.524]$} & [0.544] & {$[0.142]^{* *}$} & [0.171] \\
\hline
\end{tabular}

Characteristics of cancelled parliamentary elections (Second step of Heckman's two-step method)

Continuing next page 


\begin{tabular}{|c|c|c|c|c|c|}
\hline \multirow{9}{*}{$\begin{array}{l}\text { The characteristics of } \\
\text { the controverted } \\
\text { elections }\end{array}$} & \multirow{3}{*}{ Algeria } & (1) & (ट) & (3) & (4) \\
\hline & & 0.038 & 0.036 & 0.266 & 0.264 \\
\hline & & [0.329] & {$[0.328]$} & {$[0.337]$} & {$[0.336]$} \\
\hline & \multirow[t]{2}{*}{ 1_round } & 0.014 & 0.014 & 0.055 & 0.056 \\
\hline & & {$[0.135]$} & [0.135] & {$[0.142]$} & {$[0.142]$} \\
\hline & \multirow{2}{*}{ More2candidates } & -0.215 & -0.208 & -0.127 & -0.121 \\
\hline & & {$[0.125]^{*}$} & {$[0.125]^{*}$} & {$[0.134]$} & [0.133] \\
\hline & \multirow[t]{2}{*}{ 1candidate_2nd_round } & -0.23 & -0.221 & -0.371 & -0.362 \\
\hline & & [0.294] & [0.294] & {$[0.298]$} & {$[0.298]$} \\
\hline \multirow{24}{*}{$\begin{array}{l}\text { The authors of } \\
\text { the requests }\end{array}$} & \multirow[t]{2}{*}{ Request_Voter } & -0.213 & -0.218 & -0.154 & -0.159 \\
\hline & & {$[0.110]^{*}$} & {$[0.111]^{* *}$} & {$[0.117]$} & [0.119] \\
\hline & \multirow[t]{2}{*}{ Request_Far_Left } & 0.041 & 0.095 & 0.01 & 0.056 \\
\hline & & {$[0.434]$} & {$[0.448]$} & {$[0.436]$} & {$[0.448]$} \\
\hline & \multirow[t]{2}{*}{ Request_Com } & 0.32 & 0.31 & 0.422 & 0.412 \\
\hline & & [0.199] & [0.199] & {$[0.204]^{* *}$} & {$[0.204]^{* *}$} \\
\hline & \multirow[t]{2}{*}{ Request_Main_Left } & 0.73 & 0.719 & 0.759 & 0.748 \\
\hline & & {$[0.135]^{* * *}$} & {$[0.136]^{* * *}$} & {$[0.145]^{* * *}$} & {$[0.145]^{* * *}$} \\
\hline & \multirow[t]{2}{*}{ Request_LW } & 0.139 & 0.129 & 0.188 & 0.178 \\
\hline & & {$[0.211]$} & {$[0.211]$} & {$[0.213]$} & {$[0.213]$} \\
\hline & \multirow[t]{2}{*}{ Request_Green } & -0.19 & -0.194 & -0.106 & -0.117 \\
\hline & & {$[0.243]$} & {$[0.243]$} & [0.269] & {$[0.269]$} \\
\hline & \multirow[t]{2}{*}{ Request_Main_Right } & 0.443 & 0.427 & 0.543 & 0.526 \\
\hline & & {$[0.122]^{* * *}$} & {$[0.123]^{* * *}$} & {$[0.129]^{* * *}$} & {$[0.131]^{* * *}$} \\
\hline & \multirow[t]{2}{*}{ Request_RW } & 0.317 & 0.287 & 0.267 & 0.232 \\
\hline & & {$[0.187]^{*}$} & [0.190] & {$[0.191]$} & {$[0.194]$} \\
\hline & \multirow[t]{2}{*}{ Request_Far_Right } & 0.754 & 0.716 & 0.806 & 0.767 \\
\hline & & {$[0.141]^{* * *}$} & {$[0.143]^{* * *}$} & {$[0.151]^{* * *}$} & {$[0.154]^{* * *}$} \\
\hline & \multirow[t]{2}{*}{ Request_Independent_Ecologist } & 0.708 & 0.705 & 0.76 & 0.756 \\
\hline & & {$[0.810]$} & {$[0.808]$} & [0.825] & {$[0.822]$} \\
\hline & \multirow[t]{2}{*}{ Request_GE } & 0.126 & 0.136 & 0.062 & 0.075 \\
\hline & & [0.609] & {$[0.608]$} & {$[0.617]$} & {$[0.616]$} \\
\hline & \multirow[t]{2}{*}{ Request_Independent } & 0.062 & 0.054 & 0.178 & 0.169 \\
\hline & & [0.172] & {$[0.172]$} & {$[0.182]$} & {$[0.182]$} \\
\hline \multirow[t]{19}{*}{ The CC judges } & \multirow[t]{2}{*}{ Judges_Former Left-wing Politicians } & 1.121 & 1.124 & -0.809 & -0.8 \\
\hline & & {$[0.811]$} & {$[0.810]$} & {$[0.818]$} & {$[0.817]$} \\
\hline & Judges_Former Right-wing Politicians & -0.937 & -0.933 & 0.37 & 0.372 \\
\hline & & {$[0.650]$} & [0.649] & {$[0.538]$} & {$[0.538]$} \\
\hline & Judges_Civil servants & -0.145 & -0.164 & 0.493 & 0.467 \\
\hline & & {$[0.658]$} & {$[0.658]$} & [0.638] & {$[0.638]$} \\
\hline & Judges_Jurists & 0.044 & 0.049 & -0.812 & -0.806 \\
\hline & & [0.942] & [0.941] & {$[0.430]^{*}$} & {$[0.430]^{*}$} \\
\hline & Judges_appointed_RW & 0.549 & 0.549 & 6.12 & 6.099 \\
\hline & & [1.140] & {$[1.140]$} & {$[2.040]^{* * *}$} & {$[2.039]^{* * *}$} \\
\hline & Constant & -0.869 & -0.857 & -0.374 & -0.36 \\
\hline & & [1.162] & [1.162] & {$[0.334]$} & [0.334] \\
\hline & $\lambda$ & -0.042 & -0.039 & -0.044 & -0.047 \\
\hline & & {$[0.068]$} & {$[0.07]$} & [0.069] & {$[0.071]$} \\
\hline & Wald $(\chi 2)$ & 58.36 & 55.532 & 65.835 & 61.849 \\
\hline & Prob & 0.003 & 0.003 & 0.000 & 0.000 \\
\hline & Censored observations & 411 & 406 & 388 & 383 \\
\hline & Uncensored observations & 588 & 571 & 556 & 539 \\
\hline & Number of observations & 999 & 977 & 944 & 922 \\
\hline
\end{tabular}


Notes:

- This Table presents the results for the two-step of Heckman's two-stage estimator on all the elections whose validity was discussed by the Conseil Constitutionnel between 1958 and 2005.

- Column 1 presents the regression results on both general and by-elections whose validity was contested between 1958 and 2005. Column 2 presents the regression results on both the general and by-elections whose validity was contested between 1958 and 2005, excluding those that were held in 1986 following the proportional mode of representation. Column 3 presents the regression results on the general elections whose validity was contested between 1958 and 2002. Column 4 presents the regression results on the general elections whose validity was contested between 1958 and 2002, but excluding those that were held in 1986.

- In the second step of the regression, we included the Irregularities variable, which indicates the existence of an irregularity during the electoral campaign, but eventually had to drop it because of multicollinearity.

- Standard errors are given in brackets below the coefficients. *** indicates significance at the $1 \%$-level. ** indicates significance at the 5\%-level. * indicates significance at the $10 \%$-level. 
Table 5. Characteristics of the irregular and cancelled elections judged by the Conseil Constitutionnel when a majority of the judges was appointed by right-wing politicians.

\begin{tabular}{|c|c|c|c|c|c|}
\hline $\begin{array}{l}\text { The characteristics } \\
\text { of the controverted }\end{array}$ & Vote_Differential & $\begin{array}{l}-1.96 \mathrm{E}-06 \\
{[2.31 \mathrm{E}-6]}\end{array}$ & $\begin{array}{l}-1.15 \mathrm{E}-06 \\
{[2.26 \mathrm{E}-6]}\end{array}$ & $\begin{array}{l}-2.00 \mathrm{E}-06 \\
{[2.36 \mathrm{E}-6]}\end{array}$ & $\begin{array}{l}-1.14 \mathrm{E}-06 \\
{[2.32 \mathrm{E}-6]}\end{array}$ \\
\hline \multirow[t]{5}{*}{ elections } & 1986_elections & $\begin{array}{c}0.251 \\
{[0.398]}\end{array}$ & & $\begin{array}{c}0.566 \\
{[0.330]^{*}}\end{array}$ & \\
\hline & Algeria & $\begin{array}{c}0.087 \\
{[0.227]}\end{array}$ & $\begin{array}{l}-0.327 \\
{[0.359]}\end{array}$ & $\begin{array}{c}0.112 \\
{[0.222]}\end{array}$ & $\begin{array}{c}-0.271 \\
{[0.366]}\end{array}$ \\
\hline & 1_round & $\begin{array}{l}-0.015 \\
{[0.076]}\end{array}$ & $\begin{array}{c}0 \\
{[0.076]}\end{array}$ & $\begin{array}{c}0.009 \\
{[0.074]}\end{array}$ & $\begin{array}{c}0.021 \\
{[0.074]}\end{array}$ \\
\hline & More2candidates & $\begin{array}{c}-0.155 \\
{[0.077]^{* *}}\end{array}$ & $\begin{array}{l}-0.124 \\
{[0.078]}\end{array}$ & $\begin{array}{c}-0.157 \\
{[0.071]^{* *}}\end{array}$ & $\begin{array}{c}-0.125 \\
{[0.073]^{*}}\end{array}$ \\
\hline & 1candidate_2nd_round & $\begin{array}{c}0.268 \\
{[0.260]}\end{array}$ & $\begin{array}{c}0.274 \\
{[0.258]}\end{array}$ & $\begin{array}{c}0.289 \\
{[0.253]}\end{array}$ & $\begin{array}{c}0.296 \\
{[0.252]}\end{array}$ \\
\hline \multirow[t]{8}{*}{$\begin{array}{l}\text { Winners of the } \\
\text { controverted elections }\end{array}$} & Winner_Election_Com & $\begin{array}{c}-0.214 \\
{[0.081] * * *}\end{array}$ & $\begin{array}{c}0.01 \\
{[0.153]}\end{array}$ & $\begin{array}{c}-0.265 \\
{[0.080]^{* * *}}\end{array}$ & $\begin{array}{l}-0.055 \\
{[0.158]}\end{array}$ \\
\hline & Winner_Election_Green & $\begin{array}{c}-0.309 \\
{[0.359]}\end{array}$ & $\begin{array}{c}-0.104 \\
{[0.380]}\end{array}$ & $\begin{array}{c}-0.326 \\
{[0.348]}\end{array}$ & $\begin{array}{c}-0.137 \\
{[0.373]}\end{array}$ \\
\hline & Winner_Election_Main_Left & $\begin{array}{c}-0.064 \\
{[0.062]}\end{array}$ & $\begin{array}{c}0.119 \\
{[0.141]}\end{array}$ & $\begin{array}{c}-0.084 \\
{[0.061]}\end{array}$ & $\begin{array}{c}0.086 \\
{[0.146]}\end{array}$ \\
\hline & Winner_Election_LW & $\begin{array}{c}0.152 \\
{[0.189]}\end{array}$ & $\begin{array}{c}0.354 \\
{[0.226]}\end{array}$ & $\begin{array}{c}0.189 \\
{[0.181]}\end{array}$ & $\begin{array}{c}0.378 \\
{[0.222]^{*}}\end{array}$ \\
\hline & Winner_Election_Independent & $\begin{array}{c}-0.14 \\
{[0.092]}\end{array}$ & $\begin{array}{c}0.029 \\
{[0.144]}\end{array}$ & $\begin{array}{c}-0.131 \\
{[0.091]}\end{array}$ & $\begin{array}{c}0.023 \\
{[0.146]}\end{array}$ \\
\hline & Winner_Election_RW & $\begin{array}{c}0.042 \\
{[0.113]}\end{array}$ & $\begin{array}{c}-0.027 \\
{[0.230]}\end{array}$ & $\begin{array}{c}0.052 \\
{[0.109]}\end{array}$ & $\begin{array}{c}-0.023 \\
{[0.229]}\end{array}$ \\
\hline & Winner_Election_Main_Right & $\begin{array}{c}-0.161 \\
{[0.059]^{* * *}}\end{array}$ & $\begin{array}{c}0.048 \\
{[0.145]}\end{array}$ & $\begin{array}{c}-0.153 \\
{[0.058]^{* * *}}\end{array}$ & $\begin{array}{c}0.043 \\
{[0.150]}\end{array}$ \\
\hline & Winner_Election_Far_Right & $\begin{array}{c}0.565 \\
{[0.222]^{* *}}\end{array}$ & $\begin{array}{c}0.82 \\
{[0.261]^{* * *}}\end{array}$ & $\begin{array}{c}0.582 \\
{[0.216]^{* * *}}\end{array}$ & $\begin{array}{c}0.825 \\
{[0.254]^{* * *}}\end{array}$ \\
\hline \multirow[t]{4}{*}{ The CC judges } & Judges_Former Left-wing Politicians & $\begin{array}{c}-0.202 \\
{[0.547]}\end{array}$ & $\begin{array}{c}-0.137 \\
{[0.544]}\end{array}$ & $\begin{array}{c}0.392 \\
{[0.405]}\end{array}$ & $\begin{array}{c}0.413 \\
{[0.405]}\end{array}$ \\
\hline & Judges_Former Right-wing Politicians & $\begin{array}{c}1.016 \\
{[0.863]}\end{array}$ & $\begin{array}{c}0.935 \\
{[0.860]}\end{array}$ & $\begin{array}{c}-0.075 \\
{[0.258]}\end{array}$ & $\begin{array}{c}-0.094 \\
{[0.259]}\end{array}$ \\
\hline & Judges_Civil servants & $\begin{array}{c}0.634 \\
{[0.757]}\end{array}$ & $\begin{array}{c}0.528 \\
{[0.754]}\end{array}$ & $\begin{array}{c}0.32 \\
{[0.567]}\end{array}$ & $\begin{array}{c}0.264 \\
{[0.567]}\end{array}$ \\
\hline & Judges_Jurists & $\begin{array}{c}-0.491 \\
{[0.306]}\end{array}$ & $\begin{array}{c}-0.473 \\
{[0.304]}\end{array}$ & $\begin{array}{c}-0.145 \\
{[0.198]}\end{array}$ & $\begin{array}{c}-0.145 \\
{[0.198]}\end{array}$ \\
\hline \multirow[t]{4}{*}{ The French polity } & Senat & $\begin{array}{c}0.238 \\
{[0.205]}\end{array}$ & $\begin{array}{c}0.229 \\
{[0.203]}\end{array}$ & & \\
\hline & Cohabitation & $\begin{array}{c}0.384 \\
{[0.284]}\end{array}$ & $\begin{array}{c}0.375 \\
{[0.282]}\end{array}$ & & \\
\hline & RW_government & $\begin{array}{c}0.191 \\
{[0.129]}\end{array}$ & $\begin{array}{c}0.164 \\
{[0.128]}\end{array}$ & & \\
\hline & Constant & $\begin{array}{c}0.007 \\
{[0.316]}\end{array}$ & $\begin{array}{c}-0.148 \\
{[0.337]}\end{array}$ & $\begin{array}{c}0.42 \\
{[0.202]^{* *}}\end{array}$ & $\begin{array}{c}0.253 \\
{[0.242]}\end{array}$ \\
\hline
\end{tabular}

Characteristics of cancelled parliamentary elections (Second step of Heckman's two-step method)

(1)

(2)

(3)

(4)

[0.398]

[0.227]

$-0.015$

$-0.155$

0.268

[0.260]

.081]

$-0.309$

$-0.327$

[0.330]

0

[0.222]

[0.366]

$-0.064$

0.152

[0.189]

$0.092]$

0.042

0.113

059]***

0.565

-0.202

[0.547]

0.634

$0.306]$

0.238

0.229

0.384

0.375

$0.284]$
0.191

[0.282]

[0.129]

[0.128]

[0.316]

[0.337]

$[0.202]^{* *}$

[0.242]

Continuing next page 


\begin{tabular}{|c|c|c|c|c|c|}
\hline \multirow{9}{*}{$\begin{array}{l}\text { The characteristics of } \\
\text { the controverted } \\
\text { elections }\end{array}$} & & (1) & (2) & (3) & (4) \\
\hline & \multirow[t]{2}{*}{ Algeria } & 0.155 & 0.151 & 0.243 & 0.238 \\
\hline & & [0.337] & {$[0.336]$} & [0.339] & {$[0.338]$} \\
\hline & \multirow[t]{2}{*}{ 1st_victory } & 0.031 & 0.035 & 0.116 & 0.12 \\
\hline & & {$[0.171]$} & {$[0.171]$} & {$[0.176]$} & {$[0.176]$} \\
\hline & \multirow{2}{*}{ More2candidates } & -0.189 & -0.175 & -0.134 & -0.12 \\
\hline & & {$[0.152]$} & {$[0.152]$} & {$[0.157]$} & {$[0.157]$} \\
\hline & \multirow[t]{2}{*}{ 1candidate_2nd_round } & 0.062 & 0.068 & -0.006 & -0.002 \\
\hline & & [0.617] & [0.616] & [0.618] & [0.618] \\
\hline \multirow{20}{*}{$\begin{array}{l}\text { The authors of } \\
\text { the requests }\end{array}$} & \multirow[t]{2}{*}{ Request_Voter } & -0.358 & -0.375 & -0.332 & -0.345 \\
\hline & & {$[0.143]^{* *}$} & {$[0.147]^{* *}$} & {$[0.147]^{* *}$} & {$[0.151] * *$} \\
\hline & \multirow[t]{2}{*}{ Request_Far_Left } & -0.108 & 0.039 & -0.122 & 0.019 \\
\hline & & {$[0.643]$} & {$[0.683]$} & {$[0.642]$} & {$[0.682]$} \\
\hline & \multirow[t]{2}{*}{ Request_Com } & 0.284 & 0.259 & 0.305 & 0.281 \\
\hline & & {$[0.212]$} & {$[0.213]$} & {$[0.213]$} & {$[0.214]$} \\
\hline & \multirow[t]{2}{*}{ Request_Main_Left } & 0.675 & 0.651 & 0.684 & 0.66 \\
\hline & & {$[0.171]^{* * *}$} & {$[0.173]^{* * *}$} & {$[0.178]^{* * *}$} & {$[0.179]^{* * *}$} \\
\hline & \multirow[t]{2}{*}{ Request_LW } & 0.125 & 0.104 & 0.15 & 0.129 \\
\hline & & {$[0.236]$} & {$[0.237]$} & {$[0.238]$} & [0.239] \\
\hline & \multirow[t]{2}{*}{ Request_Green } & -0.158 & -0.186 & -0.129 & -0.157 \\
\hline & & {$[0.481]$} & {$[0.482]$} & {$[0.480]$} & {$[0.480]$} \\
\hline & \multirow{2}{*}{ Request_Main_Right } & 0.326 & 0.287 & 0.373 & 0.336 \\
\hline & & {$[0.154]^{* *}$} & {$[0.158]^{*}$} & {$[0.157]^{* *}$} & {$[0.161]^{* *}$} \\
\hline & \multirow[t]{2}{*}{ Request_RW } & 0.263 & 0.225 & 0.197 & 0.154 \\
\hline & & {$[0.230]$} & {$[0.236]$} & [0.235] & [0.241] \\
\hline & \multirow{2}{*}{ Request_Far_Right } & 0.499 & 0.398 & 0.492 & 0.39 \\
\hline & & {$[0.202]^{* *}$} & {$[0.211]^{*}$} & {$[0.205]^{* *}$} & {$[0.214]^{*}$} \\
\hline & \multirow[t]{2}{*}{ Request_Independent } & 0.029 & 0.008 & 0.091 & 0.071 \\
\hline & & {$[0.229]$} & {$[0.230]$} & {$[0.237]$} & {$[0.238]$} \\
\hline \multirow[t]{17}{*}{ The CC judges } & \multirow[t]{2}{*}{ Judges_Former Left-wing Politicians } & 1.26 & 1.291 & 0.069 & 0.111 \\
\hline & & [0.847] & [0.847] & [0.996] & [0.995] \\
\hline & \multirow[t]{2}{*}{ Judges_Former Right-wing Politicians } & -0.028 & -0.022 & 0.26 & 0.264 \\
\hline & & {$[0.604]$} & {$[0.603]$} & [0.624] & {$[0.624]$} \\
\hline & \multirow[t]{2}{*}{ Judges_Civil servants } & 2.742 & 2.714 & 1.823 & 1.8 \\
\hline & & {$[1.324]^{* *}$} & {$[1.323]^{* *}$} & [1.385] & [1.384] \\
\hline & \multirow[t]{2}{*}{ Judges_Jurists } & -0.151 & -0.133 & -0.571 & -0.552 \\
\hline & & [0.439] & [0.439] & [0.459] & [0.459] \\
\hline & \multirow[t]{2}{*}{ Constant } & -0.962 & -0.939 & -0.603 & -0.584 \\
\hline & & {$[0.391]^{* *}$} & {$[0.392]^{* *}$} & [0.408] & [0.408] \\
\hline & \multirow[t]{2}{*}{$\lambda$} & -0.104 & -0.103 & -0.108 & -0.122 \\
\hline & & [0.109] & [0.113] & {$[0.108]$} & [0.113] \\
\hline & Wald $\left(\chi^{2}\right)$ & 42.098 & 36.876 & 42.791 & 36.285 \\
\hline & Prob & 0.07 & 0.122 & 0.027 & 0.067 \\
\hline & Censored observations & 229 & 224 & 218 & 213 \\
\hline & Uncensored observations & 393 & 376 & 383 & 366 \\
\hline & Number of observations & 622 & 600 & 601 & 579 \\
\hline
\end{tabular}

Notes: This Table presents the results for the two-step of Heckman's two-stage estimator on all the elections whose validity was discussed by the Conseil Constitutionnel when a majority of judges was appointed by right-wing politicians, i.e., from 1958 to 1986, and from 2002 to 2005. 
- Column 1 presents the regression results on both general and by-elections which were controverted from 1958 to 1986, and from 2002 to 2005. Column 2 presents the regression results on both the general and by-elections which were controverted from 1958 to 1981 and from 2002 to 2005, i.e., excluding the 1986 parliamentary elections that were held following the proportional voting system. Column 3 presents the regression results on the controverted general elections, from 1958 to 1986, and in 2002. Column 4 presents the regression results on the controverted general elections, from 1958 to 1981 and in 2002, i.e., excluding the 1986 parliamentary elections.

- In the second step of the regression, we included the Irregularities variable, which indicates the existence of an irregularity during the electoral campaign, but eventually had to drop it because of multicollinearity.

- Standard errors are given in brackets below the coefficients. *** indicates significance at the $1 \%$-level. ** indicates significance at the 5\%-level. * indicates significance at the $10 \%$-level. 
Table 6. Characteristics of the irregular and cancelled elections judged by the Conseil Constitutionnel and the elections won by far-right candidates, 1958-2005

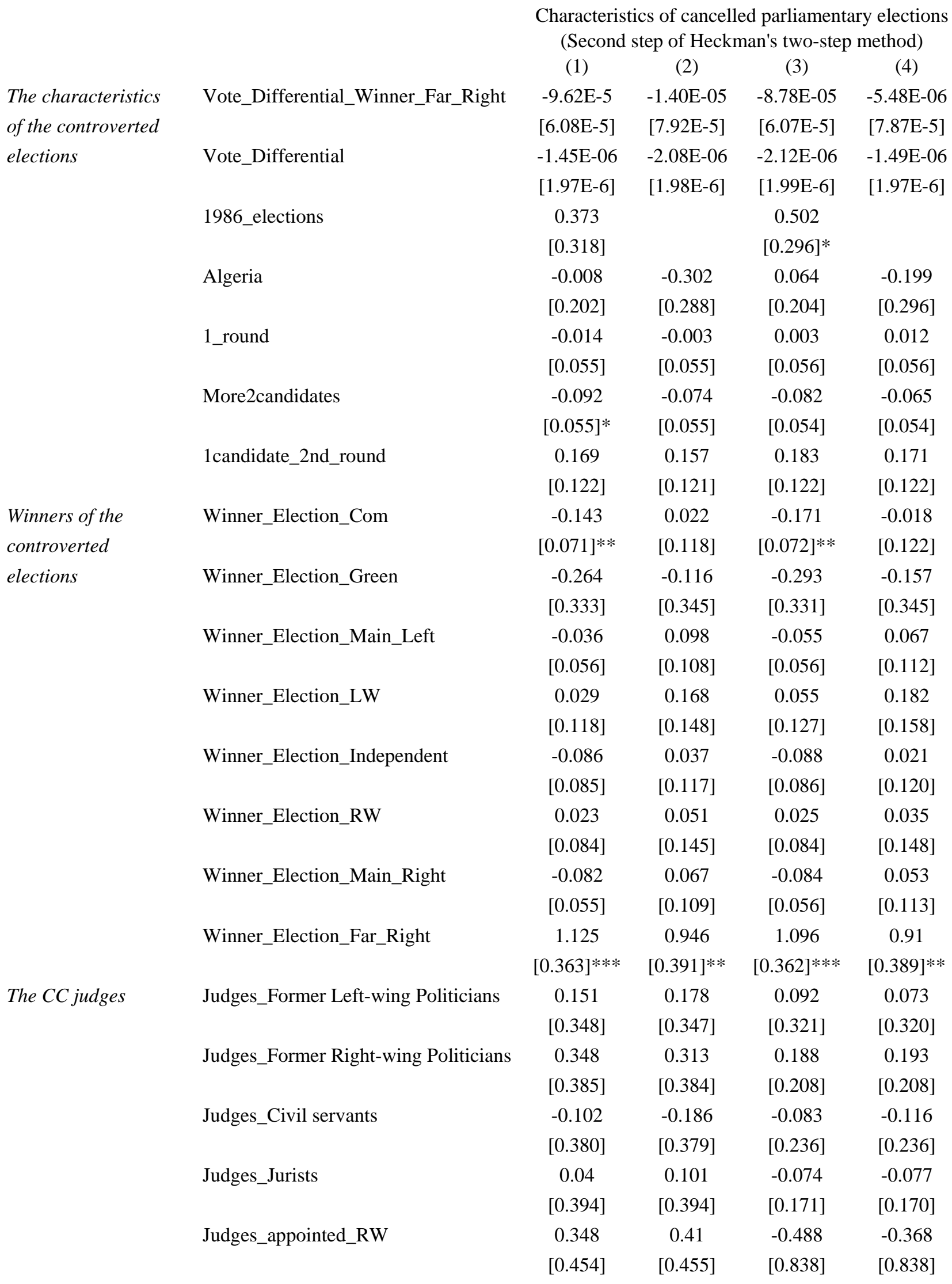

Continuing next page 


\begin{tabular}{|c|c|c|c|c|c|}
\hline \multirow[t]{10}{*}{ The French polity } & Senat & $\begin{array}{c}0.113 \\
{[0.067]^{*}}\end{array}$ & $\begin{array}{c}0.109 \\
{[0.066]}\end{array}$ & & \\
\hline & \multirow[t]{2}{*}{ Cohabitation } & 0.09 & 0.095 & & \\
\hline & & [0.099] & {$[0.098]$} & & \\
\hline & \multirow[t]{2}{*}{ RW_government } & 0.09 & 0.081 & & \\
\hline & & {$[0.088]$} & {$[0.088]$} & & \\
\hline & \multirow[t]{5}{*}{ Constant } & -0.214 & -0.413 & 0.286 & 0.157 \\
\hline & & {$[0.523]$} & {$[0.545]$} & {$[0.142]^{* *}$} & {$[0.172]$} \\
\hline & & \multirow{2}{*}{\multicolumn{4}{|c|}{$\begin{array}{l}\text { Characteristics of irregular parliamentary elections } \\
\text { (First step of Heckman's two-step method) }\end{array}$}} \\
\hline & & & & & \\
\hline & & (1) & (2) & (3) & (4) \\
\hline \multirow{8}{*}{$\begin{array}{l}\text { The characteristics of } \\
\text { the controverted } \\
\text { elections }\end{array}$} & \multirow[t]{2}{*}{ Algeria } & 0.038 & 0.036 & 0.266 & 0.264 \\
\hline & & [0.329] & {$[0.328]$} & {$[0.337]$} & {$[0.336]$} \\
\hline & \multirow[t]{2}{*}{ 1_round } & 0.014 & 0.014 & 0.055 & 0.056 \\
\hline & & {$[0.135]$} & {$[0.135]$} & {$[0.142]$} & {$[0.142]$} \\
\hline & \multirow[t]{2}{*}{ More2candidates } & -0.215 & -0.208 & -0.127 & -0.121 \\
\hline & & {$[0.125]^{*}$} & {$[0.125]^{*}$} & {$[0.134]$} & {$[0.133]$} \\
\hline & \multirow[t]{2}{*}{ 1candidate_2nd_round } & -0.23 & -0.221 & -0.371 & -0.362 \\
\hline & & [0.294] & [0.294] & {$[0.298]$} & {$[0.298]$} \\
\hline \multirow{24}{*}{$\begin{array}{l}\text { The authors of } \\
\text { the requests }\end{array}$} & \multirow[t]{2}{*}{ Request_Voter } & -0.213 & -0.218 & -0.154 & -0.159 \\
\hline & & {$[0.110]^{*}$} & {$[0.111]^{* *}$} & {$[0.117]$} & {$[0.119]$} \\
\hline & \multirow[t]{2}{*}{ Request_Far_Left } & 0.041 & 0.095 & 0.01 & 0.056 \\
\hline & & {$[0.434]$} & {$[0.448]$} & {$[0.436]$} & {$[0.448]$} \\
\hline & \multirow[t]{2}{*}{ Request_Com } & 0.32 & 0.31 & 0.422 & 0.412 \\
\hline & & [0.199] & [0.199] & {$[0.204]^{* *}$} & {$[0.204]^{* *}$} \\
\hline & \multirow[t]{2}{*}{ Request_Main_Left } & 0.73 & 0.719 & 0.759 & 0.748 \\
\hline & & {$[0.135]^{* * *}$} & {$[0.136]^{* * *}$} & {$[0.145]^{* * *}$} & {$[0.145]^{* * *}$} \\
\hline & \multirow[t]{2}{*}{ Request_LW } & 0.139 & 0.129 & 0.188 & 0.178 \\
\hline & & {$[0.211]$} & [0.211] & {$[0.213]$} & {$[0.213]$} \\
\hline & \multirow[t]{2}{*}{ Request_Green } & -0.19 & -0.194 & -0.106 & -0.117 \\
\hline & & {$[0.243]$} & {$[0.243]$} & [0.269] & [0.269] \\
\hline & \multirow[t]{2}{*}{ Request_Main_Right } & 0.443 & 0.427 & 0.543 & 0.526 \\
\hline & & {$[0.122]^{* * *}$} & {$[0.123]^{* * *}$} & {$[0.129]^{* * *}$} & {$[0.131]^{* * *}$} \\
\hline & \multirow[t]{2}{*}{ Request_RW } & 0.317 & 0.287 & 0.267 & 0.232 \\
\hline & & {$[0.187]^{*}$} & {$[0.190]$} & [0.191] & {$[0.194]$} \\
\hline & \multirow[t]{2}{*}{ Request_Far_Right } & 0.754 & 0.716 & 0.806 & 0.767 \\
\hline & & {$[0.141]^{* * *}$} & {$[0.143]^{* * *}$} & {$[0.151]^{* * *}$} & {$[0.154]^{* * *}$} \\
\hline & \multirow[t]{2}{*}{ Request_Independent_Ecologist } & 0.708 & 0.705 & 0.76 & 0.756 \\
\hline & & {$[0.810]$} & {$[0.808]$} & {$[0.825]$} & {$[0.822]$} \\
\hline & \multirow[t]{2}{*}{ Request_GE } & 0.126 & 0.136 & 0.062 & 0.075 \\
\hline & & [0.609] & {$[0.608]$} & [0.617] & {$[0.616]$} \\
\hline & \multirow[t]{2}{*}{ Request_Independent } & 0.062 & 0.054 & 0.178 & 0.169 \\
\hline & & {$[0.172]$} & {$[0.172]$} & [0.182] & [0.182] \\
\hline
\end{tabular}

Continuing next page 


$\begin{array}{llcccc}\text { The CC judges } & \text { Judges_Former Left-wing Politicians } & 1.121 & 1.124 & -0.809 & -0.8 \\ & {[0.811]} & {[0.810]} & {[0.818]} & {[0.817]} \\ & \text { Judges_Former Right-wing Politicians } & -0.937 & -0.933 & 0.37 & 0.372 \\ & {[0.650]} & {[0.649]} & {[0.538]} & {[0.538]} \\ & \text { Judges_Civil servants } & -0.145 & -0.164 & 0.493 & 0.467 \\ & {[0.658]} & {[0.658]} & {[0.638]} & {[0.638]} \\ & \text { Judges_Jurists } & 0.044 & 0.049 & -0.812 & -0.806 \\ & {[0.942]} & {[0.941]} & {[0.430]^{*}} & {[0.430]^{*}} \\ & \text { Judges_appointed_RW } & 0.549 & 0.549 & 6.12 & 6.099 \\ & {[1.140]} & {[1.140]} & {[2.040]^{* * *}} & {[2.039]^{* * *}} \\ & -0.869 & -0.857 & -0.374 & -0.36 \\ & \text { Constant } & {[1.162]} & {[1.162]} & {[0.334]} & {[0.334]} \\ & & & & \\ & & -0.045 & -0.04 & -0.048 & -0.047 \\ & {[0.068]} & {[0.07]} & {[0.069]} & {[0.071]} \\ & 61.118 & 55.565 & 68.134 & 61.854 \\ \text { Wald }(\chi 2) & 0.002 & 0.004 & 0.000 & 0.000 \\ \text { Prob } & 411 & 406 & 388 & 383 \\ \text { Censored observations } & 588 & 571 & 556 & 539 \\ \text { Uncensored observations } & 999 & 977 & 944 & 922 \\ \text { Number of observations } & & & \end{array}$

Notes:

- This Table presents the results for the two-step of Heckman's two-stage estimator on all the elections whose validity was discussed by the Conseil Constitutionnel between 1958 and 2005, where the regressions include an interaction variable between the elections won by far-right candidates and the vote differential in the controverted elections.

- Column 1 presents the regression results on both general and by-elections whose validity was contested between 1958 and 2005. Column 2 presents the regression results on both the general and by-elections whose validity was contested between 1958 and 2005, excluding those that were held in 1986 following the proportional mode of representation. Column 3 presents the regression results on the general elections whose validity was contested between 1958 and 2002. Column 4 presents the regression results only on the general elections whose validity was contested between 1958 and 2002, but excluding those that were held in 1986.

- In the second step of the regression, we included the Irregularities variable, which indicates the existence of an irregularity during the electoral campaign, but eventually had to drop it because of multicollinearity.

- Standard errors are given in brackets below the coefficients. *** indicates significance at the $1 \%$-level. ** indicates significance at the 5\%-level. * indicates significance at the $10 \%$-level. 
Table 7. Characteristics of the irregular and cancelled elections judged by the Conseil Constitutionnel when right-wing governments were in power.

\begin{tabular}{|c|c|c|c|c|c|}
\hline \multirow{6}{*}{$\begin{array}{l}\text { The characteristics of } \\
\text { the controverted } \\
\text { elections }\end{array}$} & Vote_Differential & $\begin{array}{l}-1.17 \mathrm{E}-06 \\
{[2.10 \mathrm{E}-6]}\end{array}$ & $\begin{array}{l}-2.00 \mathrm{E}-06 \\
{[2.11 \mathrm{E}-6]}\end{array}$ & $\begin{array}{l}-1.32 \mathrm{E}-06 \\
{[1.97 \mathrm{E}-6]}\end{array}$ & $\begin{array}{l}-2.13 \mathrm{E}-06 \\
{[1.99 \mathrm{E}-6]}\end{array}$ \\
\hline & 1986_elections & $\begin{array}{c}0.632 \\
{[0.368]^{*}}\end{array}$ & & $\begin{array}{c}0.6 \\
{[0.289]^{* *}}\end{array}$ & \\
\hline & Algeria & $\begin{array}{c}0.067 \\
{[0.206]}\end{array}$ & $\begin{array}{c}-0.292 \\
{[0.320]}\end{array}$ & $\begin{array}{c}0.145 \\
{[0.197]}\end{array}$ & $\begin{array}{c}-0.2 \\
{[0.296]}\end{array}$ \\
\hline & 1_round & $\begin{array}{c}-0.018 \\
{[0.063]}\end{array}$ & $\begin{array}{c}-0.004 \\
{[0.063]}\end{array}$ & $\begin{array}{c}0 \\
{[0.056]}\end{array}$ & $\begin{array}{c}0.012 \\
{[0.056]}\end{array}$ \\
\hline & More2candidates & $\begin{array}{c}-0.166 \\
{[0.073]^{* *}}\end{array}$ & $\begin{array}{c}-0.146 \\
{[0.072]^{* *}}\end{array}$ & $\begin{array}{c}-0.084 \\
{[0.055]}\end{array}$ & $\begin{array}{c}-0.065 \\
{[0.054]}\end{array}$ \\
\hline & 1candidate_2nd_round & $\begin{array}{c}0.053 \\
{[0.135]}\end{array}$ & $\begin{array}{c}0.036 \\
{[0.134]}\end{array}$ & $\begin{array}{c}0.181 \\
{[0.122]}\end{array}$ & $\begin{array}{c}0.171 \\
{[0.122]}\end{array}$ \\
\hline \multirow{8}{*}{$\begin{array}{l}\text { Winners of the } \\
\text { controverted } \\
\text { elections }\end{array}$} & Winner_Election_Com & $\begin{array}{c}-0.167 \\
{[0.075]^{* *}}\end{array}$ & $\begin{array}{c}0.04 \\
{[0.135]}\end{array}$ & $\begin{array}{c}-0.209 \\
{[0.067]^{* * *}}\end{array}$ & $\begin{array}{c}-0.018 \\
{[0.121]}\end{array}$ \\
\hline & Winner_Election_Green & $\begin{array}{c}-0.28 \\
{[0.343]}\end{array}$ & $\begin{array}{c}-0.093 \\
{[0.359]}\end{array}$ & $\begin{array}{c}-0.332 \\
{[0.331]}\end{array}$ & $\begin{array}{c}-0.156 \\
{[0.345]}\end{array}$ \\
\hline & Winner_Election_Main_Left & $\begin{array}{c}-0.086 \\
{[0.056]}\end{array}$ & $\begin{array}{c}0.077 \\
{[0.124]}\end{array}$ & $\begin{array}{c}-0.09 \\
{[0.051]^{*}}\end{array}$ & $\begin{array}{c}0.067 \\
{[0.112]}\end{array}$ \\
\hline & Winner_Election_LW & $\begin{array}{c}-0.021 \\
{[0.120]}\end{array}$ & $\begin{array}{c}0.154 \\
{[0.161]}\end{array}$ & $\begin{array}{c}0.019 \\
{[0.124]}\end{array}$ & $\begin{array}{c}0.182 \\
{[0.158]}\end{array}$ \\
\hline & Winner_Election_Independent & $\begin{array}{c}-0.125 \\
{[0.086]}\end{array}$ & $\begin{array}{c}0.024 \\
{[0.129]}\end{array}$ & $\begin{array}{c}-0.119 \\
{[0.083]}\end{array}$ & $\begin{array}{c}0.022 \\
{[0.120]}\end{array}$ \\
\hline & Winner_Election_RW & $\begin{array}{c}0.002 \\
{[0.086]}\end{array}$ & $\begin{array}{c}0.042 \\
{[0.159]}\end{array}$ & $\begin{array}{c}0.002 \\
{[0.082]}\end{array}$ & $\begin{array}{c}0.036 \\
{[0.147]}\end{array}$ \\
\hline & Winner_Election_Main_Right & $\begin{array}{c}-0.114 \\
{[0.053]^{* *}}\end{array}$ & $\begin{array}{c}0.073 \\
{[0.125]}\end{array}$ & $\begin{array}{c}-0.124 \\
{[0.049]^{* *}}\end{array}$ & $\begin{array}{c}0.054 \\
{[0.113]}\end{array}$ \\
\hline & Winner_Election_Far_Right & $\begin{array}{c}0.536 \\
{[0.212]^{* *}}\end{array}$ & $\begin{array}{c}0.817 \\
{[0.247]^{* * *}}\end{array}$ & $\begin{array}{c}0.634 \\
{[0.171]^{* * *}}\end{array}$ & $\begin{array}{c}0.887 \\
{[0.203]^{* * *}}\end{array}$ \\
\hline \multirow[t]{5}{*}{ The CC judges } & Judges_Former Left-wing Politicians & $\begin{array}{c}-0.335 \\
{[0.545]}\end{array}$ & $\begin{array}{c}-0.354 \\
{[0.538]}\end{array}$ & $\begin{array}{c}0.087 \\
{[0.322]}\end{array}$ & $\begin{array}{c}0.072 \\
{[0.320]}\end{array}$ \\
\hline & Judges_Former Right-wing Politicians & $\begin{array}{c}0.708 \\
{[0.440]}\end{array}$ & $\begin{array}{c}0.697 \\
{[0.437]}\end{array}$ & $\begin{array}{c}0.208 \\
{[0.208]}\end{array}$ & $\begin{array}{c}0.193 \\
{[0.207]}\end{array}$ \\
\hline & Judges_Civil servants & $\begin{array}{c}0.427 \\
{[0.546]}\end{array}$ & $\begin{array}{c}0.355 \\
{[0.542]}\end{array}$ & $\begin{array}{c}-0.057 \\
{[0.236]}\end{array}$ & $\begin{array}{c}-0.115 \\
{[0.235]}\end{array}$ \\
\hline & Judges_Jurists & $\begin{array}{c}-1.169 \\
{[0.883]}\end{array}$ & $\begin{array}{c}-1.2 \\
{[0.875]}\end{array}$ & $\begin{array}{c}-0.069 \\
{[0.171]}\end{array}$ & $\begin{array}{l}-0.077 \\
{[0.170]}\end{array}$ \\
\hline & Judges_appointed_RW & $\begin{array}{l}-1.121 \\
{[1.054]}\end{array}$ & $\begin{array}{c}-1.161 \\
{[1.044]}\end{array}$ & $\begin{array}{c}-0.411 \\
{[0.839]}\end{array}$ & $\begin{array}{c}-0.363 \\
{[0.835]}\end{array}$ \\
\hline \multirow[t]{3}{*}{ The French polity } & Senat & $\begin{array}{c}0.145 \\
{[0.081]^{*}}\end{array}$ & $\begin{array}{c}0.144 \\
{[0.081]^{*}}\end{array}$ & & \\
\hline & Cohabitation & $\begin{array}{c}0.015 \\
{[0.137]}\end{array}$ & $\begin{array}{c}0.013 \\
{[0.136]}\end{array}$ & & \\
\hline & Constant & $\begin{array}{c}1.394 \\
{[1.113]}\end{array}$ & $\begin{array}{c}1.276 \\
{[1.110]}\end{array}$ & $\begin{array}{c}0.309 \\
{[0.142]^{* *}}\end{array}$ & $\begin{array}{c}0.156 \\
{[0.171]}\end{array}$ \\
\hline
\end{tabular}

Continuing next page 
Characteristics of irregular parliamentary elections (First step of Heckman's two-step method)
(1)
(2)
(3)
(4)

The characteristics
the controverted
elections
The authors of
the requests

The CC judges
Algeria
1_round
More2candidates
1candidate_2nd_round

Request_Voter

Request_Far_Left

Request_Com

Request_Main_Left

Request_LW

Request_Green

Request_Main_Right

Request_RW

Request_Far_Right

Request_Independent_Ecologist

Request_GE

Request_Independent

Judges_Former Left-wing Politicians

Judges_Former Right-wing Politicians

Judges_Civil servants

Judges_Jurists

Judges_appointed_RW

Constant

$\lambda$

$\operatorname{Wald}\left(\chi^{2}\right)$

Prob

Censored observations

Uncensored observations

Number of observations

$\begin{array}{cccc}0.087 & 0.075 & 0.266 & 0.264 \\ {[0.330]} & {[0.331]} & {[0.336]} & {[0.336]} \\ 0.042 & 0.038 & 0.055 & 0.056 \\ {[0.155]} & {[0.155]} & {[0.142]} & {[0.142]} \\ -0.332 & -0.333 & -0.126 & -0.121\end{array}$

$[0.143]^{* *} \quad[0.145]^{* *} \quad[0.132] \quad[0.133]$

$\begin{array}{llll}-0.209 & -0.2 & -0.371 & -0.362\end{array}$

$\left[\begin{array}{llll}0.321] & {[0.322]} & {[0.298]} & {[0.298]}\end{array}\right.$

$\begin{array}{llll}-0.26 & -0.27 & -0.154 & -0.159\end{array}$

$[0.124]^{* *} \quad[0.126]^{* *} \quad[0.117] \quad[0.119]$

$\begin{array}{llll}0.009 & 0.069 & 0.009 & 0.056\end{array}$

$[0.434] \quad[0.449] \quad[0.435] \quad[0.448]$

$\begin{array}{llll}0.374 & 0.356 & 0.422 & 0.412\end{array}$

$[0.209]^{*} \quad[0.210]^{*} \quad[0.204]^{* *} \quad[0.204]^{* *}$

$\begin{array}{llll}0.701 & 0.68 & 0.76 & 0.748\end{array}$

$[0.154]^{* * *} \quad[0.156]^{* * *} \quad[0.145]^{* * *} \quad[0.145]^{* * *}$

$\begin{array}{llll}0.151 & 0.129 & 0.188 & 0.178\end{array}$

$\left[\begin{array}{llll}0.238] & {[0.239]} & {[0.212]} & {[0.213]}\end{array}\right.$

$\begin{array}{llll}-0.113 & -0.129 & -0.106 & -0.117\end{array}$

$\left[\begin{array}{llll}0.276 & {[0.276]} & {[0.269]} & {[0.269]}\end{array}\right.$

$\begin{array}{llll}0.469 & 0.44 & 0.543 & 0.526\end{array}$

$[0.136]^{* * *} \quad[0.138]^{* * *} \quad[0.129]^{* * *} \quad[0.131]^{* * *}$

$\begin{array}{llll}0.402 & 0.372 & 0.267 & 0.232\end{array}$

$[0.207]^{*} \quad[0.212]^{*} \quad[0.191] \quad[0.194]$

$\begin{array}{llll}0.689 & 0.643 & 0.806 & 0.767\end{array}$

$\left[\begin{array}{llll}0.152]^{* * *} & {[0.155]^{* * *}} & {[0.151]^{* * *}} & {[0.154]^{* * *}}\end{array}\right.$

$\begin{array}{llll}-5.434 & -5.474 & 0.762 & 0.756\end{array}$

$\left[\begin{array}{llll}{[0.000]} & {[0.000]} & {[0.824]} & {[0.822]}\end{array}\right.$

$\begin{array}{llll}-0.231 & -0.218 & 0.062 & 0.075\end{array}$

$\left[\begin{array}{llll}{[0.671]} & {[0.669]} & {[0.617]} & {[0.616}\end{array}\right.$

$\begin{array}{llll}0.032 & 0.012 & 0.179 & 0.169\end{array}$

$[0.200] \quad[0.202] \quad[0.181] \quad[0.182]$

$\begin{array}{llll}-0.907 & -0.622 & -0.823 & -0.8\end{array}$

$\left[\begin{array}{llll} & {[0.946]} & {[1.149]} & {[0.693]}\end{array}\right]$

$\begin{array}{llll}0.325 & 0.271 & 0.368 & 0.372\end{array}$

$\left[\begin{array}{llll}0.779] & {[0.790]} & {[0.535]} & {[0.538]}\end{array}\right.$

$\begin{array}{llll}0.979 & 1.117 & 0.494 & 0.467\end{array}$

$\left[\begin{array}{llll} & {[1.288]} & {[1.333]} & {[0.638}\end{array}\right][0.638]$

$\begin{array}{llll}-2.755 & -2.621 & -0.815 & -0.806\end{array}$

$[1.352]^{* *} \quad[1.386]^{*} \quad[0.417]^{*} \quad[0.430]^{*}$

$\begin{array}{llll}-3.136 & -2.991 & 6.137 & 6.099\end{array}$

$[1.709]^{*} \quad[1.745]^{*} \quad[1.970]^{* * *}[2.039]^{* * *}$

$\begin{array}{llll}2.908 & 2.724 & -0.37 & -0.36\end{array}$

$[1.698]^{*} \quad[1.764] \quad[0.315] \quad[0.334]$

$\begin{array}{llll}-0.005 & -0.012 & -0.044 & -0.047\end{array}$

$\left[\begin{array}{llll}{[0.081]} & {[0.083]} & {[0.069]} & {[0.071]}\end{array}\right.$

$\begin{array}{llll}44.533 & 41.727 & 65.843 & 61.849\end{array}$

$\begin{array}{llll}0.043 & 0.059 & 0.000 & 0.000\end{array}$

$\begin{array}{llll}323 & 318 & 388 & 383\end{array}$

$\begin{array}{llll}482 & 465 & 556 & 539\end{array}$

$\begin{array}{llll}805 & 783 & 944 & 922\end{array}$ 
Notes:

- This Table presents the results for the two-step of Heckman's two-stage estimator on all the elections whose validity was discussed by the Conseil Constitutionnel when right-governments were in power, i.e., between 1958 and 1981, 1986 and 1988, 1993 and 1997, 2002 and 2005.

- Column 1 presents the regression results on both general and by-elections whose validity was contested between 1958 and 2005. Column 2 presents the regression results on both the general and by-elections whose validity was contested between 1958 and 2005, excluding those that were held in 1986 following the proportional mode of representation. Column 3 presents the regression results on the general elections whose validity was contested between 1958 and 2002. Column 4 presents the regression results on the general elections whose validity was contested between 1958 and 2002, but excluding those that were held in 1986.

- In the second step of the regression, we included the Irregularities variable, which indicates the existence of an irregularity during the electoral campaign, but eventually had to drop it because of multicollinearity.

- Standard errors are given in brackets below the coefficients. *** indicates significance at the $1 \%$-level. ** indicates significance at the 5\%-level. * indicates significance at the $10 \%$-level. 
Figure 1. Shares of judges appointed by mainstream left-wing and mainstream right-wing politicians sitting on the Conseil Constitutionnel bench in the years of general parliamentary elections.

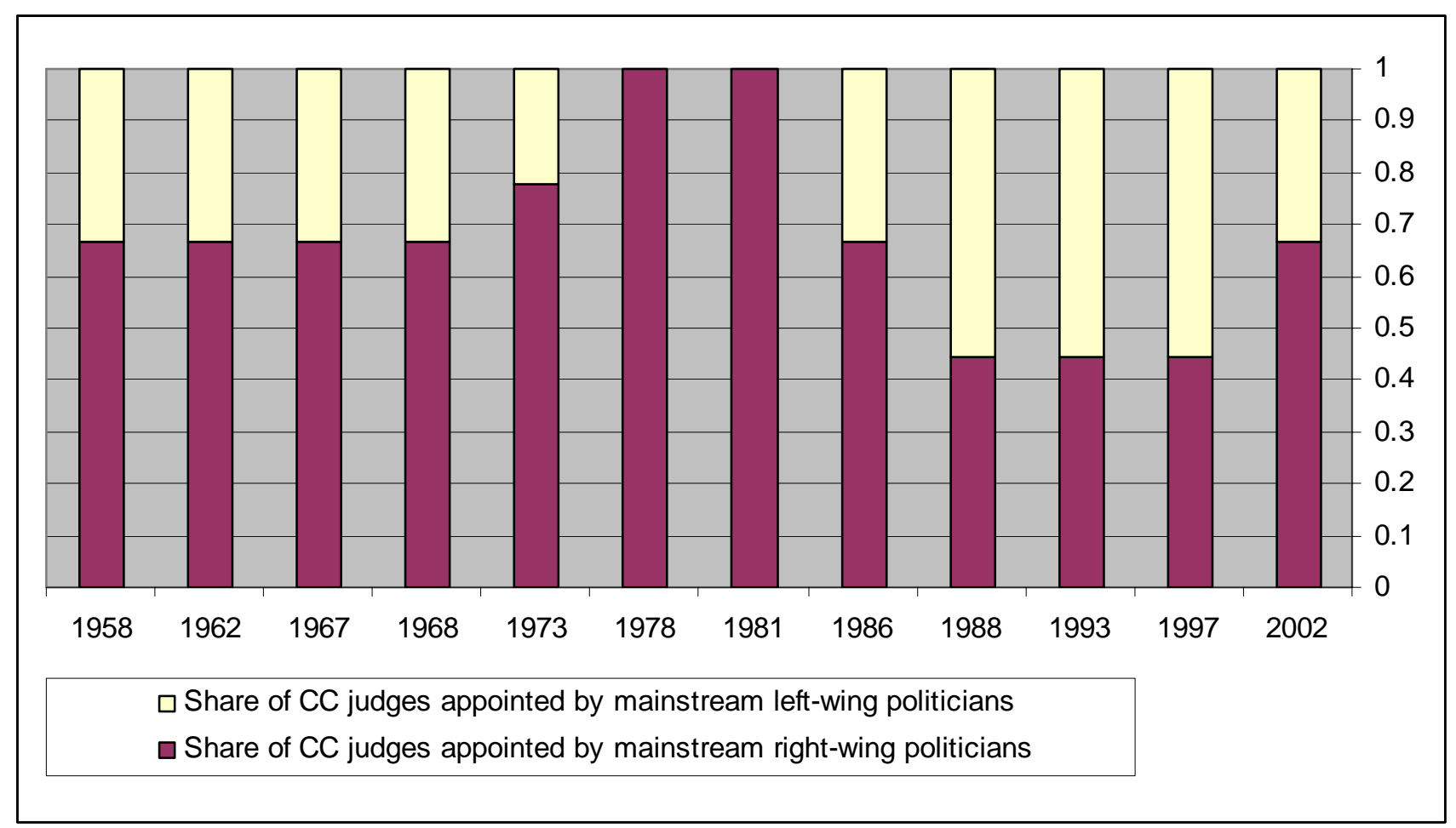




\section{Bar-Ilan University \\ Department of Economics \\ WORKING PAPERS}

1-01 The Optimal Size for a Minority

Hillel Rapoport and Avi Weiss, January 2001.

2-01 An Application of a Switching Regimes Regression to the Study of Urban Structure

Gershon Alperovich and Joseph Deutsch, January 2001.

3-01 The Kuznets Curve and the Impact of Various Income Sources on the Link Between Inequality and Development

Joseph Deutsch and Jacques Silber, February 2001.

4-01 International Asset Allocation: A New Perspective

Abraham Lioui and Patrice Poncet, February 2001.

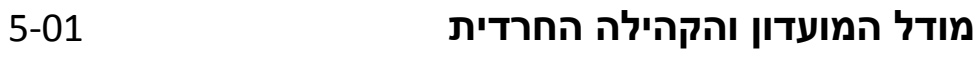

$$
\text { יעקב רוזנברג, פברואר } 2001 .
$$

6-01 Multi-Generation Model of Immigrant Earnings: Theory and Application Gil S. Epstein and Tikva Lecker, February 2001.

7-01 Shattered Rails, Ruined Credit: Financial Fragility and Railroad Operations in the Great Depression

Daniel A. Schiffman, February 2001.

8-01 Cooperation and Competition in a Duopoly R\&D Market

Damiano Bruno Silipo and Avi Weiss, March 2001.

9-01 A Theory of Immigration Amnesties

Gil S. Epstein and Avi Weiss, April 2001.

10-01 Dynamic Asset Pricing With Non-Redundant Forwards Abraham Lioui and Patrice Poncet, May 2001.

11-01 Macroeconomic and Labor Market Impact of Russian Immigration in Israel Sarit Cohen and Chang-Tai Hsieh, May 2001.

Electronic versions of the papers are available at http://www.biu.ac.il/soc/ec/wp/working_papers.html 
12-01 Network Topology and the Efficiency of Equilibrium Igal Milchtaich, June 2001.

13-01 General Equilibrium Pricing of Trading Strategy Risk Abraham Lioui and Patrice Poncet, July 2001.

14-01 Social Conformity and Child Labor Shirit Katav-Herz, July 2001.

15-01 Determinants of Railroad Capital Structure, 1830-1885 Daniel A. Schiffman, July 2001.

16-01 Political-Legal Institutions and the Railroad Financing Mix, 1885-1929 Daniel A. Schiffman, September 2001.

17-01 Macroeconomic Instability, Migration, and the Option Value of Education Eliakim Katz and Hillel Rapoport, October 2001.

18-01 Property Rights, Theft, and Efficiency: The Biblical Waiver of Fines in the Case of Confessed Theft

Eliakim Katz and Jacob Rosenberg, November 2001.

19-01 Ethnic Discrimination and the Migration of Skilled Labor Frédéric Docquier and Hillel Rapoport, December 2001.

1-02 Can Vocational Education Improve the Wages of Minorities and Disadvantaged Groups? The Case of Israel

Shoshana Neuman and Adrian Ziderman, February 2002.

2-02 What Can the Price Gap between Branded and Private Label Products Tell Us about Markups?

Robert Barsky, Mark Bergen, Shantanu Dutta, and Daniel Levy, March 2002.

3-02 Holiday Price Rigidity and Cost of Price Adjustment Daniel Levy, Georg Müller, Shantanu Dutta, and Mark Bergen, March 2002.

4-02 Computation of Completely Mixed Equilibrium Payoffs Igal Milchtaich, March 2002.

5-02 Coordination and Critical Mass in a Network Market - An Experimental Evaluation Amir Etziony and Avi Weiss, March 2002. 
6-02 Inviting Competition to Achieve Critical Mass

Amir Etziony and Avi Weiss, April 2002.

7-02 Credibility, Pre-Production and Inviting Competition in a Network Market Amir Etziony and Avi Weiss, April 2002.

8-02 Brain Drain and LDCs' Growth: Winners and Losers Michel Beine, Fréderic Docquier, and Hillel Rapoport, April 2002.

9-02 Heterogeneity in Price Rigidity: Evidence from a Case Study Using MicroLevel Data

Daniel Levy, Shantanu Dutta, and Mark Bergen, April 2002.

10-02 Price Flexibility in Channels of Distribution: Evidence from Scanner Data Shantanu Dutta, Mark Bergen, and Daniel Levy, April 2002.

11-02 Acquired Cooperation in Finite-Horizon Dynamic Games Igal Milchtaich and Avi Weiss, April 2002.

12-02 Cointegration in Frequency Domain Daniel Levy, May 2002.

13-02 Which Voting Rules Elicit Informative Voting? Ruth Ben-Yashar and Igal Milchtaich, May 2002.

14-02 Fertility, Non-Altruism and Economic Growth: Industrialization in the Nineteenth Century

Elise S. Brezis, October 2002.

15-02 Changes in the Recruitment and Education of the Power Elitesin Twentieth Century Western Democracies

Elise S. Brezis and François Crouzet, November 2002.

16-02 On the Typical Spectral Shape of an Economic Variable Daniel Levy and Hashem Dezhbakhsh, December 2002.

17-02 International Evidence on Output Fluctuation and Shock Persistence Daniel Levy and Hashem Dezhbakhsh, December 2002.

1-03 Topological Conditions for Uniqueness of Equilibrium in Networks Igal Milchtaich, March 2003.

2-03 Is the Feldstein-Horioka Puzzle Really a Puzzle? Daniel Levy, June 2003. 
3-03 Growth and Convergence across the US: Evidence from County-Level Data Matthew Higgins, Daniel Levy, and Andrew Young, June 2003.

4-03 Economic Growth and Endogenous Intergenerational Altruism Hillel Rapoport and Jean-Pierre Vidal, June 2003.

5-03 Remittances and Inequality: A Dynamic Migration Model Frédéric Docquier and Hillel Rapoport, June 2003.

6-03 Sigma Convergence Versus Beta Convergence: Evidence from U.S. CountyLevel Data

Andrew T. Young, Matthew J. Higgins, and Daniel Levy, September 2003.

7-03 Managerial and Customer Costs of Price Adjustment: Direct Evidence from Industrial Markets

Mark J. Zbaracki, Mark Ritson, Daniel Levy, Shantanu Dutta, and Mark Bergen, September 2003.

8-03 First and Second Best Voting Rules in Committees

Ruth Ben-Yashar and Igal Milchtaich, October 2003.

9-03 Shattering the Myth of Costless Price Changes: Emerging Perspectives on Dynamic Pricing

Mark Bergen, Shantanu Dutta, Daniel Levy, Mark Ritson, and Mark J. Zbaracki, November 2003.

1-04 Heterogeneity in Convergence Rates and Income Determination across U.S. States: Evidence from County-Level Data

Andrew T. Young, Matthew J. Higgins, and Daniel Levy, January 2004.

2-04 "The Real Thing:" Nominal Price Rigidity of the Nickel Coke, 1886-1959 Daniel Levy and Andrew T. Young, February 2004.

3-04 Network Effects and the Dynamics of Migration and Inequality: Theory and Evidence from Mexico

David Mckenzie and Hillel Rapoport, March 2004.

4-04 Migration Selectivity and the Evolution of Spatial Inequality Ravi Kanbur and Hillel Rapoport, March 2004.

5-04 Many Types of Human Capital and Many Roles in U.S. Growth: Evidence from County-Level Educational Attainment Data

Andrew T. Young, Daniel Levy and Matthew J. Higgins, March 2004. 
6-04 When Little Things Mean a Lot: On the Inefficiency of Item Pricing Laws Mark Bergen, Daniel Levy, Sourav Ray, Paul H. Rubin and Benjamin Zeliger, May 2004.

7-04 Comparative Statics of Altruism and Spite Igal Milchtaich, June 2004.

8-04 Asymmetric Price Adjustment in the Small: An Implication of Rational Inattention

Daniel Levy, Haipeng (Allan) Chen, Sourav Ray and Mark Bergen, July 2004.

1-05 Private Label Price Rigidity during Holiday Periods Georg Müller, Mark Bergen, Shantanu Dutta and Daniel Levy, March 2005.

2-05 Asymmetric Wholesale Pricing: Theory and Evidence Sourav Ray, Haipeng (Allan) Chen, Mark Bergen and Daniel Levy, March 2005.

3-05 Beyond the Cost of Price Adjustment: Investments in Pricing Capital Mark Zbaracki, Mark Bergen, Shantanu Dutta, Daniel Levy and Mark Ritson, May 2005.

4-05 Explicit Evidence on an Implicit Contract Andrew T. Young and Daniel Levy, June 2005.

5-05 Popular Perceptions and Political Economy in the Contrived World of Harry Potter

Avichai Snir and Daniel Levy, September 2005.

6-05 Growth and Convergence across the US: Evidence from County-Level Data (revised version)

Matthew J. Higgins, Daniel Levy, and Andrew T. Young, September 2005.

1-06 Sigma Convergence Versus Beta Convergence: Evidence from U.S. CountyLevel Data (revised version)

Andrew T. Young, Matthew J. Higgins, and Daniel Levy, June 2006.

2-06 Price Rigidity and Flexibility: Recent Theoretical Developments Daniel Levy, September 2006.

3-06 The Anatomy of a Price Cut: Discovering Organizational Sources of the Costs of Price Adjustment

Mark J. Zbaracki, Mark Bergen, and Daniel Levy, September 2006. 
4-06 Holiday Non-Price Rigidity and Cost of Adjustment

Georg Müller, Mark Bergen, Shantanu Dutta, and Daniel Levy.

September 2006.

2008-01 Weighted Congestion Games With Separable Preferences

Igal Milchtaich, October 2008.

2008-02 Federal, State, and Local Governments: Evaluating their Separate Roles in US Growth

Andrew T. Young, Daniel Levy, and Matthew J. Higgins, December 2008.

2008-03 Political Profit and the Invention of Modern Currency

Dror Goldberg, December 2008.

2008-04 Static Stability in Games

Igal Milchtaich, December 2008.

2008-05 Comparative Statics of Altruism and Spite

Igal Milchtaich, December 2008.

2008-06 Abortion and Human Capital Accumulation: A Contribution to the Understanding of the Gender Gap in Education

Leonid V. Azarnert, December 2008.

2008-07 Involuntary Integration in Public Education, Fertility and Human Capital

Leonid V. Azarnert, December 2008.

2009-01 Inter-Ethnic Redistribution and Human Capital Investments

Leonid V. Azarnert, January 2009.

2009-02 Group Specific Public Goods, Orchestration of Interest Groups and Free Riding

Gil S. Epstein and Yosef Mealem, January 2009.

2009-03 Holiday Price Rigidity and Cost of Price Adjustment

Daniel Levy, Haipeng Chen, Georg Müller, Shantanu Dutta, and Mark Bergen, February 2009.

2009-04 Legal Tender

Dror Goldberg, April 2009.

2009-05 The Tax-Foundation Theory of Fiat Money

Dror Goldberg, April 2009. 
2009-06 The Inventions and Diffusion of Hyperinflatable Currency

Dror Goldberg, April 2009.

2009-07 The Rise and Fall of America's First Bank

Dror Goldberg, April 2009.

2009-08 Judicial Independence and the Validity of Controverted Elections

Raphaël Franck, April 2009.

2009-09 A General Index of Inherent Risk

Adi Schnytzer and Sara Westreich, April 2009.

2009-10 Measuring the Extent of Inside Trading in Horse Betting Markets

Adi Schnytzer, Martien Lamers and Vasiliki Makropoulou, April 2009.

2009-11 The Impact of Insider Trading on Forecasting in a Bookmakers' Horse Betting Market

Adi Schnytzer, Martien Lamers and Vasiliki Makropoulou, April 2009. 